\title{
Rafrænar ferilbækur sem leið að aukinni námsvitund. Starfendarannsókn í sjónlistum
}

\author{
Sandra Rebekka Önnudóttir Arnarsdóttir, \\ Hermína Gunnpórsdóttir og Jórunn Elídóttir \\ Abstract $>$ Um höfundana $>$ About the authors $>$ Heimildir
}

Hér er greint frá starfendarannsókn um próun rafrænna ferilbóka í sjónlistum á unglingastigi sem fór fram skólaárið 2017-2018. Tilgangurinn var að efla nám með pví að skapa sameiginlega sýn og samábyrgð nemenda og kennara og stuðla að aukinni einstaklingsmiðun. Innleiddar voru ferilbækur sem tilraun til pess að stuðla að fyrrnefndum páttum. Markmiðið var að ég ${ }^{1}$ sem kennari lærði af eigin vinnu og mótaði starfshætti par sem nemendum eru gefin aukin tækifæri til pess að takast á við námið á eigin forsendum. Rannsóknarspurningin sem lagt var upp með var: Hvernig má nota rafrænar ferilbækur til pess að auka einstaklingsmiðun í sjónlistakennslu? Gagnaöflun var margpæett og fólst í skráningum í rannsóknardagbók, samtölum í umræðuhópum nemenda og rýniviðtölum við úrtak úr nemendahópnum, rafrænni könnun meðal nemenda og mati á rafrænum ferilbókum peirra. Niðurstöður benda til pess að rafrænar ferilbækur hafi haft margpættan ávinning, bæði fyrir nemendur mína og mig sem kennara. Dær reyndust vera leið til pess að auka einstaklingsmiðun í kennslu minni í sjónlistum og pær gáfu nemendum aukna yfirsýn á nám sitt. Einnig sýndu niðurstöður að ferilbækur voru vettvangur til ígrundunar pegar markvissum námsstuðningi var beitt. Rafrænar ferilbækur reyndust einnig vera leið til pess að veita mér sem kennara aukna yfirsýn á nám og framför nemenda.

Efnisorð: Rafrænar ferilbækur, sjónlistir, einstaklingsmiðun, ígrundun, námsvitund

\section{Inngangur}

Opinber menntastefna landsins er byggð á hugmyndum um skóla án aðgreiningar sem leggur pá ábyrgð á herðar kennurum að mæta pörfum allra nemenda (Stjórnarráð Íslands, e.d.). Menntavísindastofnun Háskóla Íslands (e.d.) skilgreinir skóla án aðgreiningar sem stefnu sem leggi áherslu á vandaða menntun allra. Hún snýr að bættri menntun kennara, skipulagi skóla, námi og kennslu í ljósi lýðræðis og félagslegs réttlætis í skólum. Stefnan felur í sér pá hugsun að námspörfum allra nemenda eigi að mæta í almennum skóla og að einblína skuli á að útrýma námsog félagslegum hindrunum í námsumhverfinu. Skóli án aðgreiningar á við um alla nemendur (Thomas, 2013) og felur í sér að peir, óhád pví hvort um sé að ræða skilgreinda námspörf eða ekki, geti tekið pátt í náminu og að viðeigandi pörfum peirra sé mætt. Hugmyndafræðin byggir á réttindum einstaklinga til fullgildrar pátttöku í skólasamfélaginu par sem hugað er að jöfnuði allra án aðgreiningar á hvaða grundvelli sem er. Skóli án aðgreiningar á að vera skóli sem aðgreinir ekki nemendur á nokkurn hátt, hvorki út frá stétt, stöðu, útliti né öðru (Anna Kristín Sigurðardóttir, 2013). Grundvöllur skóla án aðgreiningar er einstaklingsmiðað nám. Drátt fyrir að notkun orðasambandsins sé nokkuð ný af nálinni virðist umræðan vera mun eldri en notkun orðsins sjálfs en undir lok síðustu aldar fór að bera á stefnumótun sem leggur áherslu á að mæta pörfum hvers og eins nemanda (Ingvar Sigurgeirsson, 2005). 
Til pess að geta tekist á við kennslu nemendahópa með fjölbreyttar námsparfir purfa kennarar að nýta margs konar aðferðir sem henta ólíkum einstaklingum. Баð getur verið tímafrekt og krefjandi innan pess ramma sem kennarar starfa. Dað er bví mikill ávinningur af pví að geta nýtt aðferðir sem hver og einn nemandi getur lagað að eiginleikum sínum og nýtt ólíka tjáningarmáta og fjölbreytt mat. Sem sjónlistakennari í grunnskóla glími ég daglega við pað verkefni að finna leiðir til pess að gefa nemendum færi á fjölbreyttum tjáningaraðferðum og leiðum til aðlögunar. Sjónlistir bjóđa í eðli sínu upp á annars konar tjáningu en hefðbundin bókleg fög. Nemendur eru pó ólíkir og hentar fagið peim misvel. Dví parf ég, líkt og aðrir kennarar, að leggja mig fram við að bjóða nemendum upp á sem fjölbreyttastar leiðir til bæði tjáningar og aðlögunar. Í meistaranámi mínu við Háskólann á Akureyri kviknaði áhugi minn á einstaklingsmiðuðu námi. Ég fann bæði pörf og kröfu um að auka einstaklingsmiðun í eigin kennslu og finna leiðir sem gætu auðveldað mér að mæta pví markmiði.

Kennsla í sjónlistum felur í sér að nemendur vinna fjölda verkefna sem peir purfa að halda utan um. Eitt helsta áhersluatriði Aðalnámskrár grunnskóla (Mennta- og menningarmálaráðuneyti, 2013), í hæfniviðmiðum list- og verkgreinakennslu, er mikilvægi pess að nemendur geti sýnt og útskýrt eigið vinnuferli sem feli í sér próun frá hugmynd yfir í eigið verk. Detta markmið má finna bæði í sameiginlegum hæfniviðmiðum allra listgreina, par sem petta er fyrsta markmiðið sem nefnt er fyrir öll stig grunnskólans, og í hæfniviðmiðum sjónlista. Dað skiptir máli hvernig haldið er utan um pessa vinnu og hvort verkefnum nemenda sé gert hátt undir höfði eða ekki. Ferilbækur geta verið leið að pessu markmiði en pær eru pekkt fyrirbrigði í ýmsum greinum, bæði innan menntakerfisins og annars staðar. Listamenn og hönnuðir hafa lengi notað ferilbækur, bæði sem skissubækur sem ekki voru ætlaðar til skoðunar fyrir aðra en pá sjálfa og einnig til pess að sýna verk sín, oft í peim tilgangi að sækjast eftir verkefnum en pá er gjarnan um að ræða samansafn af bestu verkum viðkomandi (Barrett, 2011; Fahey og Cronen, 2016). Með pví að halda utan um verkefni nemenda og gæta peirra, er lögð áhersla á mikilvægi vinnu nemenda.

Í stefnumótun um og upp úr síðustu aldamótum, pegar umræðan um sveigjanlega kennsluhætti fór að verða áberandi, var lögð áhersla á kennsluhætti par sem stuðst væri við upplýsinga- og samskiptatækni. Enn fremur var bent á að ein forsenda pess að hægt væri að efla einstaklingsmiðað nám væri að stuðla að aukinni tölvuvæðingu í grunnskólum (Fræðslumiðstöð Reykjavíkur, 1998, 1999). Stefnumótunin er einnig skýr í Adalnámskrá grunnskóla (Mennta- og menningarmálaráđuneyti, 2013) par sem lögð er áhersla á að nám eigi að vera á forsendum nemenda og kennsluhættir og námsumhverfi eigi að taka mið af getu nemenda. Dar er einnig nefnt að námsgögn og kennslutæki skuli vera valin til pess að styðja við nám nemenda. Pví er ljóst að tækni hefur í einhvern tíma verið talin tækifæri til pess að auka einstaklingsmiðun í námi.

\section{Bakgrunnur rannsóknar}

Áður en að pessari rannsókn kom, innleiddi ég notkun ápreifanlegra ferilbóka á pappír í sjónlistakennslu minni, sem tilraun til að mæta pessu markmiði aðalnámskrár (Mennta- og menningarmálaráđuneyti, 2013). Prátt fyrir að pað hafi gengið að mestu leyti vel, komu fljótlega í ljós nokkrir vankantar. Sá helsti var hversu óumhverfisvænar ferilbækurnar voru par sem mikill pappír fór í gerð peirra. Einnig buðu pær eingöngu upp á takmarkaða notkun miðla. Ef um var аð ræða ljósmyndir eða vélritaðan texta, pá purfti að prenta pað út. Nemendur gátu heldur ekki sett tónlist, kvikmyndir eða annað efni í bókina, nema pá að vísa í slóðirnar. Pá var einnig erfitt fyrir nemendur að tengja vinnu sína í skóla við veru utan skóla par sem bókin var föst í skólanum en nemendur fengu ekki að taka hana með heim fyrr en í lok annar par sem ekki var hægt að treysta á að nemendur kæmu með bókina í alla tíma. Dannig nýttist ferilbókin ekki sem skyldi og nemendur unnu misvel að henni. Dví beindist áhugi minn fljótlega að möguleikum tækninnar og gerð rafrænna ferilbóka til pess að mæta betur ólíkum pörfum nemenda.

Dví purfti ég að finna betri leiðir og finna forrit sem hentaði starfskenningu minni, aðstöðu og skipulagi í skólanum en ekki síður peim tækjakosti sem var til. Forritið purfti pví að mæta 
nokkrum skilyrðum. Рað varð að virka í iOS stýrikerfinu par sem skólinn á iPad spjaldtölvur og pær ganga á pví kerfi. Hins vegar taldi ég pað vera sérstakan kost ef forritið virkaði bæði í iOS og Android stýrikerfunum par sem pað opnaði fyrir pann möguleika að nemendur gætu nýtt eigin snjalltæki í náminu, bæði í skóla og heima. Miklu máli fannst mér skipta að hægt væri að setja sem flestar tegundir af rafrænum gögnum í ferilbækurnar, myndir, myndbönd, hljóð og texta. Sérstakur kostur var ef hægt var að setja inn glærusýningar, hlaða upp skrám og greypa (e. embed) gögn inn í bókina. Dá fannst mér mikilvægt að hægt væri að aðlaga bókina að smekk hvers og eins og að hún veitti sjónræna yfirsýn. Einnig pótti mér mikilvægt að forritið byði upp á að hver og einn nemandi væri með sína eigin ferilbók en einnig að nemendur hefðu aðgang að sameiginlegu svæði par sem kennari gæti sett inn efni og leiðbeiningar. Ég vildi að hægt væri að stjórna aðgengi að ferilbókunum pannig að gögn nemenda væru örugg en að sama skapi varð ég að hafa greiðan aðgang að peim til leiðbeiningar og mats. Par sem um tilraunastarfsemi í grunnskóla var að ræða, mátti forritið ekki vera kostnaðarsamt. Ég kynnti mér eftirfarandi forrit; Weebly, Padlet, Dreamdo, Seesaw, Evernote, Voice Thread, Fresh Grade, Sesame og Edusight og bar pau saman, varð Padlet (https://padlet.com/) fyrir valinu par sem forritið bauð upp á pá eiginleika sem leitað var eftir og var einnig einfalt í notkun.

Tilgangur rannsóknarinnar sem hér er kynnt var að skapa námsmenningu í skólastofunni sem styður við nám, bæði mitt sem kennara, og nemenda minna, með pví að skapa sameiginlega sýn og samábyrgð. Dví var farin sú leið að styðjast við aðferðafræði starfendarannsókna. Markmiðið var að ég lærði af eigin vinnu og mótaði starfshætti par sem nemendur hefðu aukin tækifæri til pess að takast á við námið á eigin forsendum. Rannsóknin var hluti af meistaraprófi mínu. Rannsóknarspurningin sem lagt var upp með var: Hvernig má nota rafrænar ferilbækur í sjónlistakennslu á unglingastigi í grunnskóla til pess að auka einstaklingsmiðun? Um var að ræða rafrænar ferilbækur til pess að skrásetja ferli nemenda í sjónlistarnámi peirra. Deim stóð til boða að skrásetja pað á pann hátt sem peir kusu og nýttu til pess iPad spjaldtölvur. Rannsóknina má finna á vefsvæðinu https://listaspira.wixsite.com/rafraenarferilbaekur

\section{Rafrænar ferilbækur}

Ferilbækur eiga sér langa sögu en rafrænar ferilbækur (e. digital portfolios/electronic portfolio/efolio) eru tiltölulega nýjar af nálinni. Dær eru, líkt og nafnið gefur til kynna, eingöngu á rafrænu formi og með peim opnast ýmsir möguleikar sem hin hefðbundna ferilbók býr ekki yfir. Með tilkomu netsins hefur ferilbókagerð öðlast áður ópekkta kosti og möguleikar peirra margfaldast. Hefðbundnar ferilbækur bjóða ekki upp á sömu skilvirkni og pær rafrænu gera par sem hægt er að setja inn fjölbreyttar færslur og tengja ýmiss konar gögn við ferilbækurnar með ofurmiðlun (e. hypermedia) (Barrett, 2011; Chi-Cheng og Bing-Hong, 2012). Dá taka rafrænar ferilbækur ekki rými, nema stafrænt rými (Canada, 2002) og eru oft mun ódýrari en hefðbundnar ferlibækur (Heath, 2005). Rafrænar ferilbækur mætti pví skilgreina sem samansafn af margmiðlunarverkum nemenda sem eru geymd rafrænt (Niguidula, 2005).

Megintilgangur ferilbóka er almennt að halda utan um verk nemenda (Chi-Cheng og BingHong, 2012). Hins vegar má sjá nýrri dæmi um ferilbókagerð í skólum í annars konar tilgangi (Barrett, 2011; Hicks, Russo, Autrey, Gardner, Kabodian og Edington, 2007), til dæmis sem leið að aukinni ígrundun. Ferilbækur hafa verið nýttar til pess að koma bestu verkum nemenda á framfæri, sýna fram á að nemendur hafi mætt markmiðum, skjalfesta framfarir nemenda í námi, bæði yfir lengri og styttri tíma, halda til haga sýnidæmum úr völdum eða öllum fögum yfir tiltekið tímabil, halda utan um ákveðið verkefni eða afmarkað ferli og miðla verkum nemenda til kennara, skólasystkina, foreldra og annarra ef við á (Niguidula, 2005). Dó svo að ferilbækur hafi margvíslegan tilgang má segja að helst sé um prjá meginpætti að ræða; til pess að sýna ákveðið og afmarkað ferli, til pess að sýna bestu afurð af heild og til pess að safna saman gögnum fyrir mat (Abrami og Barrett, 2005; Fahey og Cronen, 2016). Markmið ferilbókanna hefur áhrif á hvað í pær er sett. Ef markmiðið er að fylgjast með pví hvort nemendur mæta tilteknum markmiðum 
purfa kennarar að bjóđa nemendum upp á endurtekin tækifæri til pess að sýna fram á pað. Ef tilgangurinn er hins vegar að sýna fram á framfarir nemenda parf að raða sýnidæmum í rétta röð til að ná yfirsýn (Niguidula, 2005).

\section{Helstu kostir rafrænna ferilbóka}

Degar unnið er með rafrænar ferilbækur eru ýmis atriði sem parf að íhuga. Gæta parf pess að hafa skýra sýn á hvaða hæfni er sóst eftir og hvert innihald ferilbókanna skal vera; hver tilgangurinn sé með pví að safna verkum nemenda saman; hverjir hafi aðgang að bókunum; hvort hægt sé að nýta innihaldið við mat; hvaða tækni er til staðar sem getur nýst við gerð bókanna og; hvernig best sé að safna efni í bækurnar (Niguidula, 2005). Snið ferilbóka getur einnig verið margvíslegt og byggir að einhverju leyti á pví hver tilgangur peirra er. Nota má kerfi sem hafa sérstaklega verið hönnuð fyrir skóla eða stofnanir par sem sniðið er fyrirfram ákveðið og nemendur fylla í raun inn í pað (Chi-Cheng og Bing-Hong, 2012). Aðrir hafa nýtt bloggsniðið par sem nemendur setja inn færslur og geta sett inn athugasemdir við færslur annarra (Hicks o.fl., 2007). Hins vegar eru til margvísleg forrit sem gefa ýmsa möguleika í gerð rafrænna ferilbóka par sem byrjað er frá grunni og nemendur hanna sjálfir útlit og snið. Möguleikarnir eru pví margs konar, allt eftir tilgangi bókanna (Hicks o.fl., 2007).

\section{Umgjörð og yfirsýn á nám}

Rafrænar ferilbækur auðvelda kennara að halda utan um nám nemenda, hvort heldur sem er almennt, á ákveðnu tímabili eða í ákveðnum verkefnum. Námið verður sýnilegra og auðveldara er að festa fingur á framfarir í námi (Niguidula, 2005, bls. 45), bæði fyrir kennara og nemendur en einnig foreldra og aðra sem málið gæti varðað. Með heildrænu utanumhaldi öðlast bæði nemendur og kennarar betri yfirsýn á nám nemenda, framfarir og aðferðir (Chi-Cheng og Bing-Hong, 2012). Баð getur hjálpað sumum nemendum að fá pessa yfirsýn á nám sitt og verkefni sem peir vinna og á pað sérstaklega við um nemendur sem nýta helst hægra heilahvelið til náms og hugsa sjónrænt (Reid, 2005).

Einn helsti kostur rafrænna ferilbóka er pví sá að sýna nemendum hvernig peir byggja á fyrri pekkingu og eflast og proskast. Dannig getur sjálfstraust peirra aukist sem hefur bein áhrif á námsárangur (Niguidula, 2005). Með pví að skapa umgjörð og halda utan um eigið nám getur ferilbókagerð gefið nemendum tækifæri til pess að vera virkir pátttakendur 1 eigin merkingarsköpun (Love og Cooper, 2004) ásamt að gefa peim tækifæri til ríkari hlutdeildar í eigin námi og aukið eignarhald nemenda (Abrami og Barret, 2005; Heide, Karlin, Miles og Ozogul, 2016). Pegar nemendur takast á við verkefni sem peir hafa gott vald á getur skuldbinding peirra aukist (Shernoff, Csikszentmihalyi, Schneider og Shernoff, 2014; Wang og Holcombe, 2010).

\section{Aðlögun og sjálfstceði i námi}

Rafrænar ferilbækur bjóða upp á marga möguleika pegar kemur að aðlögun í námi. Nemendur geta fengið tækifæri til pess að sníða ferilbækurnar að eigin pörfum, bæði hvað varðar útlit, skipulag og innihald. Einn helsti kostur við rafræna útfærslu ferilbóka er sá að hægt er að leggja áherslu á ólíka tjáningarmiðla (Hicks o.fl., 2007; Niguidula, 2005) og veita nemendum tækifæri til pess að sýna fram á skilning sinn með peim tjáningarmáta sem peim hentar.

Í ákveðnum tilfellum gæti nemendum pótt betra að vinna rafrænt, hvort sem um er að ræða skrif, lestur, teikningu, hönnun eða annað pess háttar. Dað hindrar hins vegar ekki pá sem kjósa að gera fyrrnefnd atriði á hefðbundinn hátt, til að mynda að handskrifa texta eða teikna á blað par sem peir geta fært pá vinnu yfir á rafrænt form inn í ferilbókina. Með rafrænum ferilbókum aukast pví möguleikarnir við að læra á fjölbreyttan hátt par sem áhersla er lögð á leiðir til náms frekar en veikleika nemenda. Detta viðhorf styður við félagslega sýn á fötlun par sem áhersla er lögðá færni og jöfn lífsgæði (Norwich, 2013) fremur en veikleika og vöntun. 
Með peirri auknu aðlögun á námi sem rafrænar ferilbækur geta veitt, gefst nemendum einnig færi á að sýna sjálfstæði í námi (Niguidula, 2005). Nemendur með leshömlun geta nýtt sér snjalltæki og forrit til pess að skanna inn texta, láta talgervil lesa upp leiðbeiningar, skrifa svör á lyklaborð, taka upp hljóð eða myndband. Detta geta peir gert án pess að kennarinn purfi að aðstoða pá sérstaklega. Рað gefur peim færi á að vinna samhliða jafningjum sínum í stað pess að telja sig vanhæfa, sem er mikilvægt ef nám á að eiga sér stað (Reid, 2005). Áríðandi er að nemendur geti mætt peim kröfum sem á pá eru lagðar og hafi verkfæri í höndunum sem peir purfa til að ná markmiðum sínum eins og Norwich (2013) bendir á. Í pví samhengi geta ferilbækur verið eitt peirra verkfæra.

\section{Ígrundun og námsvitund}

Rafrænar ferilbækur eru tilvalinn vettvangur fyrir ígrundun nemenda par sem peir lýsa og greina eigið nám (Hicks o.fl., 2007; Niguidula, 2005). Ferlið sem á sér stað við gerð rafrænna ferilbóka er hugsað sem leið til pess að ígrunda eigið nám, íhuga hvað viðkomandi er nú pegar búinn að gera og kynnast ólíkum aðferðum og miðlum sem má nota í námi (Hicks o.fl., 2007). Í eðli sínu gefur ferilbókagerð nemendum tækifæri á að skapa merkingu úr eigin upplifun með markvissri ígrundun líkt og Ma og Rada (2005) benda á. Cleveland (2018) segir að oft hafi reynst erfitt að innleiða reglulega ígrundun í nám og kennslu. Til að auðvelda ígrundun bendir Niguidula (2005) kennurum á að nota kveikju eða spurningar til pess að aðstoða nemendur við ígrundunina. Pegar nemendur purfa að færa rök fyrir pví af hverju ákveðin færsla mætir peim kröfum sem gerðar eru eða hvernig hún tengist námi peirra, pá öðlast peir aukinn skilning á pví hvað felst í markmiðunum. Með betri yfirsýn á námsferilinn, hafa nemendur fleiri tækifæri til pess að vera meðvitaðri um раð sem peir gera dags daglega og hvernig peir byggja upp pekkingu sína. Sér í lagi á petta við ef nemendur purfa að íhuga hvernig verk peirra tengjast námi og proska.

Námsvitund er nemendum nauðsynleg til að auka námsárangur og yfirfæra pekkingu á önnur fög og með bættri yfirsýn og ígrundun má stuðla að aukinni námsvitund (Barrett, 2011; Reid, 2005). Rafrænar ferilbækur bjóða einnig upp á ólíka nálgun eða útfærslur eftir pörfum nemenda og geta pví nýst við að aðlaga nám að námsstíl peirra, en líkt og Reid (2005) segir pá getur aukin aðlögun að námsstíl nemenda stuðlað að aukinni námsvitund. Eisner (2002) tekur í sama streng og segir að í gegnum ferilbókagerð fái nemendur tækifæri til að sýna fram á pað sem peir hafa lært. Rafrænar ferilbækur gefa peim tækifæri til að túlka og ígrunda ferlið sem getur haft áhrif á námsvitund peirra. Í stað pess að fá beina kennslu sem miðar að yfirfærslu upplýsinga, geta ferilbækur verið leið til pess að gefa nemendum færi á að skapa eigin pekkingu út frá eigin reynslu par sem pekkingin er aukaafurð ferlisins (Fahey og Cronen, 2016). Darling (2001) heldur pó fram að ígrundun sé nemendum ekki töm og purfi peir mikla handleiðslu og pjálfun pegar að peim pætti kemur.

\section{Takmarkanir rafræenna ferilbóka}

prátt fyrir að rannsóknir sýni að rafrænar ferilbækur geti haft jákvæð áhrif á gæði náms eru pær ekki gallalausar. Nemendur eru margvíslegir og parfnast mismunandi aðferða. Rafræn vinna hentar pví ekki öllum. Almennt getur notkun rafrænna ferilbóka pó aukið frammistöðu nemenda pegar kemur að markmiðasetningu, ígrundun, sjálfsmati og jafningjamati, samskiptum og samvinnu, gagnasöfnun, skipulagi, samfelldri framför og lausnamiðaðri hugsun (Chi-Cheng og Bing-Hong, 2012).

\section{Krafa um búnad}

Баð fyrsta sem parf að huga að við gerð rafrænna ferilbóka er nauðsynlegur tækjabúnaður, en án fullnægjandi nettengingar og aðgangi að tölvum eða snjalltækjum, er hæpið að hægt sé að útbúa góðar ferilbækur sem endurspegla nám nemenda (Heath, 2005; Pecheone, Pigg, Chung og Souviney, 2005). Möguleiki er á að samnýta pann búnað sem er til í skólum en vissulega getur verið að engin tæki séu til staðar. Skortur á tækjabúnaði er pví hindrun í gerð rafrænna ferilbóka (Tosh, Light, Fleming og Haywood, 2005). 
Einhverjum getur pótt tæknin flókin og vinnan við ferilbækurnar fyrirhafnarmikil. Dar má nýta markvissan námsstuðning og gæta pess að leiða nemendur skref fyrir skref í gegnum nýjar aðferðir og forrit líkt og Dickson, Chard og Simmons (1993) leggja áherslu á. Pannig fá nemendur pann stuðning sem peir purfa á að halda til pess að temja sér nýja hæfni og geta beitt pekkingu án aðstoðar (Rosenshine og Meister, 1992) og fikrað sig áfram að aukinni ábyrgð á eigin námi sem og námi samnemenda (Wass, Harland og Mercer, 2011).

\section{Krafa um skýr markmið}

Niguidula (2005) telur að mikilvægara sé að huga að markmiðum, tilgangi og mati heldur en tækninni sem slíkri. Hicks o.fl. (2007) taka í sama streng og halda pví fram að pó að tæknin bjóði upp á ríkulegt námsferli sem er í págu bæði nemenda og kennara, verði pað að byggja á peim kröfum sem námskrár setja, pví án viðmiða eru rafrænar ferilbækur eingöngu margmiðlunarkynningar eða úrklippubækur.

Árangur af notkun rafrænna ferilbóka tengist pví peim markmiðum sem sett eru við gerð peirra. Gerðar hafa verið ýmsar rannsóknir á hvernig ferilbækur eru metnar og hvort slíkt mat sé marktækt. Rannsakendur hafa lýst pví yfir að pörf sé á að próa gagnlega matskvarða sem eru hannaðir til pess að meta rafrænar ferilbækur. Рað krefst pó mikillar vinnu að útbúa vandaða kvarða (Niguidula, 2005; Zeichner og Wray, 2001). Smith og Tillema (2003) taka fram að pó til séu kvarðar til að meta hefðbundnar ferilbækur. Hins vegar bjóða rafrænar ferilbækur upp á áður ópekkta kosti í ferilbókagerð og pví er nauðsynlegt að aðlaga kvarðana til pess að gera ráð fyrir margmiðlun, framsetningu upplýsinga og uppsetningu. Dau telja einnig að petta pýði ekki að pau gögn sem styðja áreiðanleika mats á hefðbundnum ferilbókum eigi síður við um mat á rafrænum ferilbókum. Hins vegar er í pessum matskvörðum oft áhersla á færslur nemenda í stað pess að meta pað nám sem átti sér stað (Chi-Cheng og Bing-Hong, 2012).

Hicks o.fl. (2007) segja ennfremur áhersluna í rannsóknum á árangri rafrænna ferilbóka pví miður vera á mat á kostnað ígrundunar. Hefðbundið mat takmarkast pví oft við skrifaðan texta sem nemendum er oft ekki töm tjáningaraðferð og getur pað takmarkað mat.

\section{Krafa um vel unnið starf}

Dað getur bví verið vandasamt að útbúa gagnlega rafræna ferilbók. Dað krefst tíma, skuldbindingar og seiglu, bæði af hálfu nemenda og kennara (Chi-Cheng og Bing-Hong, 2012). Detta á sér í lagi við pegar verið er að innleiða gerð rafrænna ferilbóka. Drátt fyrir góðan undirbúning kennara er eins víst að peir rekist á ýmsar hindranir pegar peir tileinka sér áđur ópekkt vinnubrögð. Að sama skapi getur nemendum pótt erfitt að breyta um starfshætti og mæta nýjum kröfum (Hauge, 2006). Аð öllu sögðu eru pó fjölmargir kostir pví samfara að nota rafrænar ferilbækur og ekki pá síst par sem ætlunin er að draga fram ferli, próun eða auðvelda mat, par með talið í listgreinum.

\section{Aðferð}

Rannsóknaraðferðin er starfendarannsókn en meginmarkmið peirra er að tengja saman starf og rannsóknir með pví að kennarar sjálfir prófa tiltekna aðferð eða íhlutun við raunverulegar aðstæður. Starfendarannsóknir fela í sér endurtekið hringferli nokkurra grunnpátta og teljast til eigindlegra rannsóknaraðferða. Safna parf gögnum til að greina upphafsstöðu og fylgjast með peim breytingum sem eiga sér stað (Kristín Pórarinsdóttir og Rúnar Sigpórsson, 2013).

Starfendarannsóknir tengja saman rannsóknir og starf par sem rannsakandinn, eða pátttakendur, skoða og ígrunda eigið starf, aðstæður og íhlutun með раð аð markmiði að breyta peim. Rannsakandinn er pannig alltaf hluti af rannsókninni og eru slíkar rannsóknir oft einnig kallaðar pátttökurannsóknir (Jóhanna Einarsdóttir, 2009; Kristín Dórarinsdóttir og Rúnar Sigpórsson, 2013; McNiff og Whitehead, 2010). Degar kennarar vinna starfendarannsókn í skóla pá er athyglinni beint að eigin kennslu og áhrifum hennar á nemendur. Tilgangur hennar nær til rannsakandans sjálfs, starfs hans og starfsaðstæðna. 
Séreinkenni starfendarannsóknar er að rannsakandinn er sjálfur hluti af rannsókninni. Pannig beinast slíkar rannsóknir að auknum starfsproska, bættum starfsaðstæðum og jafnvel umbótum par sem rannsakandinn er miðpunktur rannsóknarinnar. Detta er pví rannsóknaraðferð sem hjálpar kennurum að læra og vaxa í starfi (Hafpór Guðjónsson, 2011; Kristín Dórarinsdóttir og Rúnar Sigpórsson, 2013; McNiff og Whitehead, 2010). Par sem helsti kostur starfendarannsókna er sá að rannsakandinn breytir eigin starfsháttum í samræmi við niðurstöðurnar og próar starf sitt áfram (Mills, 2007) pá féll pessi aðferð vel að markmiðum rannsóknarinnar sem voru að ég lærði af eigin vinnu og mótaði starfshætti par sem nemendur hafa aukin tækifæri til pess að takast á við námið á eigin forsendum, par sem áherslan var jafnframt á að efla nám nemenda með pví að skapa sameiginlega sýn og samábyrgð.

Rannsóknin fór fram í sjónlistakennslu á elsta stigi grunnskóla veturinn 2017-2018 og náđi til ellefu hópa nemenda í áttunda, níunda og tíunda bekk, alls 87 barna, 50 stúlkna og 37 drengja. Skipulagið í skólanum gerði ráð fyrir að í sjónlistastofunni væru fimm kennslutímabil par sem ólíkir hópar nemenda tækju pátt en alls tóku prjátíu og prír nemendur pátt í fleiru en einu tímabili og sumir tóku pátt í premur.

\section{Gagnaöflun og úrvinnsla}

Ákvarðanirnar um umgjörð utan um ferilbækurnar byggðu á ákveðinni forvinnu skólaárin tvö á undan. Ég gerði tilraun með að nemendahópar unnu hefðbundnar ferilbækur á pappír og aðrir hópar notuðu rafrænar ferilbækur en árangurinn af bví síðarnefnda var misjafn, ekki síst vegna pess að rafrænu tækin dugðu ekki nægilega vel. Til pess að átta mig á hvað gekk vel og hvað síður safnaði ég gögnum um kennslu mína petta skólaár.

Gagnasöfnun fólst 1 eftirfarandi páttum:

1. Fyrsta kennslustund hvers tímabils hófst á umræðu milli kennara og nemenda par sem færi gafst á að ræða fyrirhugaða íhlutun, p.e. gerð ferilbóka. Nemendur höfðu tækifæri til að tjá skoðanir sínar á fyrirkomulaginu og koma með athugasemdir sem og tillögur til breytinga. Niðurstöður voru skráðar og nýttar til að próa kennsluna.

2. Ég hélt rannsóknardagbækur og skráði meðal annars punkta og athugasemdir varðandi framgang verkefnisins jafnt og pétt allan tímann. Gögnin voru nýtt sem grunnur að breyttu fyrirkomulagi á næsta tímabili.

3. Nemendur svöruðu einnig rafrænni könnun í lok hvers tímabils og lögðu mat á eigin reynslu. Spurningarnar voru 8-10 talsins, unnar út frá markmiðum rannsóknarinnar og gáfu hugmyndir um pað sem gekk vel eða mátti bæta. Allar spurningar voru opnar.

4. Rafrænu ferilbækurnar voru gögn í sjálfu sér og voru grunnurinn að mati á frammistöðu nemenda sem og framgangi rannsóknarinnar. Ég skoðaði pær og greindi sniðmát sem nemendur völdu, fjölda færslna, gæði færslna, fjölda rafrænna verkfæra og miðla og bar pær saman við pær ferilbækur sem til voru frá fyrra skólaári og nefndar eru hér framar.

5. Að lokum fólst gagnaöflun í premur rýniviðtölum sem tekin voru í lok skólaárs. Tóku fjórir nemendur pátt í hverju viðtali en peir áttu pað sameiginlegt að hafa tekið pátt í sjónlistatímabilum oftar en einu sinni.Viðtalið var tekið upp og afritað, niðurstöður ígrundaðar og að lokum pemagreindar.

Greining gagnanna fólst í pví að í lok tímabilanna endurskoðaði ég íhlutunina og endurmat hana í ljósi gagna sem fyrir lágu en við lok skólaársins dró ég heildarniðurstöðu af vinnunni. Stöðug ígrundun var hluti af ferlinu enda grundvöllur pess að aðferðin virkaði sem skyldi (Jóhanna Einarsdóttir, 2009) og voru dagbækur, ferilbækur og niðurstöður rýniviðtala í sífelldri skoðun sem leiddi af sér breytingar á starfinu (Kristín Dórarinsdóttir og Rúnar Sigpórsson, 2013; McNiff, 2013). Ríkustu gögnin komu úr rýniviðtölunum. Rýnt var í samtölin og pau pemu greind sem komu endurtekið upp en pau voru umgjörð um nám, einstaklingsmiðun, eignarhald, skuldbinding, sjálfstæði í námi, ígrundun, námsstuðningur og námsvitund. 
Umræður nemenda og kennara, rafrænu kannanirnar og rannsóknardagbækurnar nýttust mér til pess að endurskoða og ígrunda ferlið og aðlaga íhlutunina á milli tímabila.

\section{Réttmæti rannsóknarinnar}

Allra nauðsynlegra leyfa fyrir rannsókninni var aflað. Foreldrar nemendanna voru upplýstir um rannsóknina með kynningarbréfi og var litið á pá kynningu sem ígildi upplýsts sampykkis. Einnig var nemendum kynnt hvað fólst í rannsókninni og höfðu peir val um hvort peir tækju pátt eða ekki. Pátttaka í rýnihópum var val nemenda en allir sem fengu boð páðu pað. Foreldrar peirra voru upplýstir um pann pátt sérstaklega og gefinn kostur á að koma með athugasemdir eða afpakka pátttöku. Krafan um upplýst sampykki er mikilvæg skylda rannsakenda, bæði siðferðilega og lagalega. Nemendur purfa að vita hvað mun gerast, hvernig gögnin verða notuð og að peir geti dregið sig út úr rannsókn hvenær sem er (Mukherji og Albon, 2010; Sigurður Kristinsson, 2003) og var pess gætt í hvívetna. Nafnleyndar var gætt og ekki er fjallað um einstaka nemendur á persónugreinanlegan hátt.

Siðferðilegt jafnræði innan rannsókna, sérstaklega með börnum, er til vill ekki fullkomlega mögulegt (Mauthner, 1997). Eðli málsins samkvæmt er rannsakandinn sem kennarií valdahlutverki og er pví tilteknum vanda bundið að gæta jafnræðis, ná fram hugmyndum nemenda og gefa peim vægi. Ástríður Stefánsdóttir (2013) bendir á að rannsóknargögnin eru undir áhrifum af pekkingu og reynslu pess sem rannsakar, og pví getur verið að ekki sé alltaf augljóst að hvaða leyti rannsakandinn mótar eða hefur áhrif á pá atburðarás sem er til athugunar Dessi atriði voru höfð til hliðsjónar í samskiptum og skipulagi minnar rannsóknar.

Önnur mikilvæg siðferðisspurning felst í að rannsóknin snýr að listum og sköpunarferli nemenda (Nutbrown, 2010) en erfitt getur reynst að fylgja siðferðilegum viðmiðum aðferðafræði rannsókna pegar kemur að listsköpun barna og línan á milli pess að gefa börnum færi á pátttöku og pess að ganga ekki of langt er fín. Nutbrown (2010) segir að aukin áhersla á velferð barna sem pátttakendur í rannsóknum hafi leitt af sér viðurkenndar aðferðir sem hamli pví að rödd barna og sýn fái að heyrast. Mikilvægt sé að rödd barna heyrist en einnig parf að gæta að velferð peirra og rétt á nafnleysi í rannsóknum. Dví fólst meginspurningin í hvort líta ætti á sköpunarferli nemenda líkt og pað birtist í ferilbókum peirra, sem viðkvæmar persónuupplýsingar. Í bókunum birtast verk nemenda, hugsanir peirra og mat á eigin vinnu. Parna takast á tveir heimar, annars vegar heimur fræða og rannsókna sem takmarkast af ýmsum reglum og viðmiðum og heimur lista par sem allt aðrar reglur eiga við eða engar reglur (Nutbrown, 2010).

Ferilbækur nemenda voru gögn í rannsókninni og farið með pær sem slík. Dær voru eingöngu aðgengilegar peim sjálfum, kennara og foreldrum. Hins vegar voru einstaka nemendur sem veittu leyfi til pess að ferilbækur peirra væru nýttar sem sýnidæmi. Dær bækur voru afritaðar og öllum persónugreinanlegum gögnum eytt úr peim.

\section{Niðurstöður og umræða}

Niðurstöður rannsóknarinnar sýndu sex pemu sem verða kynnt í samsvarandi undirköflum ásamt fræðilegri umræðu; umgjörð um nám, einstaklingsmiðun, eignarhald og skuldbinding, ígrundun, námsstuðningur og námsvitund.

\section{Umgjörð um nám}

Rafræna könnunin og rýniviðtölin bentu til pess að ferilbókagerðin veitti nemendum aðgengi að verkfæri til pess að halda utan um og skrásetja eigið nám. Könnunin leiddi endurtekið í ljós ánægju nemenda með að eiga ferlið skrásett. Við lok 5. tímabils sögðu til dæmis 29 nemendur af 30 að peim hefði líkað að skrásetja ferlið í ferilbók en einn nemandi sagði að pað hefði getað 
gengið betur. Pá voru peir nemendur sem komu oftar en einu sinni í sjónlistir mjög jákvæðir en 33 nemendur tóku pátt í tveim eða fleiri tímabilum. Rýniviðtölin staðfestu petta pegar nemendur sögðu ,,..ég hefði ekki getað haldið utan um petta jafn vel“ og „,pað var pægilegt að hafa öll verkin sín á sama stað“. Í rýniviðtölum tóku 11 nemendur af 12 fram að peim pætti hjálplegra að gera ferilbók en ekki, sem endurspeglast í orðunum „,pað er miklu hjálplegra að hafa petta svona“ og „,petta er miklu betra en pað var“. Einn nemandi vildi frekar einbeita sér eingöngu að verkinu sjálfu, fremur en skrásetningu á ferlinu. Ferilbækurnar sjálfar voru í öllum tilfellum ítarlegri en árið áður, færslur voru fleiri par sem ígrundun hvers tíma og styttri heimaverkefni voru hluti af bókunum. Ferlið var einnig sýnt á áður ópekktan hátt með myndum eða myndskeiðum. Detta samræmist niðurstöðum Chi-Cheng og Bing-Hong (2012) sem telja heildræna sýn á ferilinn vera einn helsta kost ferilbóka.

Aðspurðir tóku nemendur ítrekað fram að skipulag væri einn mikilvægasti páttur ferilbókagerðarinnar en í rafrænu könnuninni var pað nefnt hvað oftast sem mikilvægur páttur eða alls 28 sinnum, sjá Mynd 1. Tveir nemendur tóku fram í rafrænni könnun að peir hefðu viljað geta gert möppur til pess að skipuleggja ferilbókina enn betur. Aðrir kunnu pó að meta pessa sjónrænu yfirsýn og sagði einn nemandi í rafrænni könnun „,pað er gott að geta litið yfir námið“. Rýniviðtölin staðfestu petta pegar nemandi sagði „við sjáum öll verkin“. Reid (2005) sýndi einmitt fram á að pað sé mörgum nemendum mikilvægt að hafa sjónræna yfirsýn og gott skipulag á náminu, sem sé einn kostur ferilbóka. Rafræna könnunin leiddi í ljós að 20 nemendur af 87 töldu pó flókið að gera rafræna ferilbók og 1 nemandi vildi annaðhvort gera ferilbók á hefðbundinn hátt eða sleppa ferilbókagerðinni alveg.

Pættir sem nemendur töldu sig hafa grætt á ferilbókagerðinni

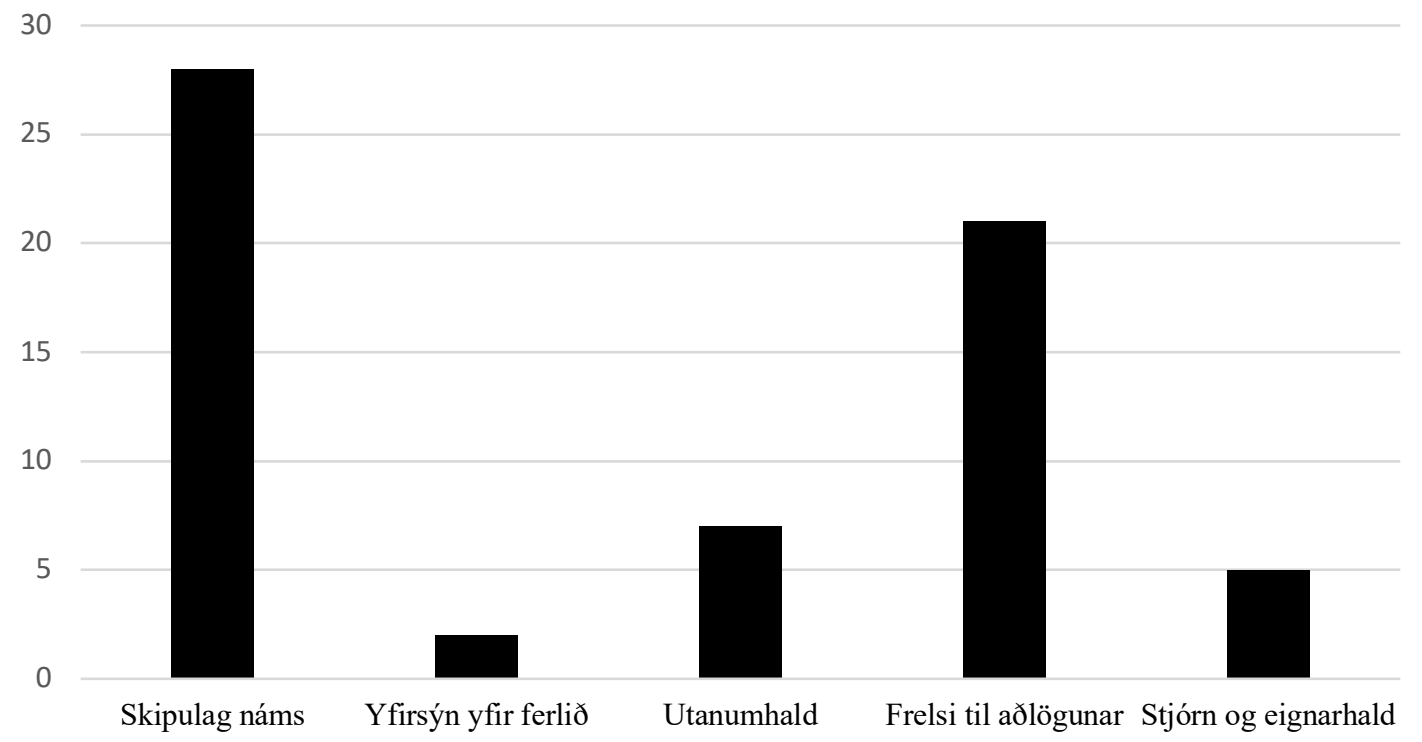

Mynd 1. Dættir sem nemendur töldu sig hafa grætt á ferilbókagerðinni samanber rafræna könnun.

Í rýniviðtölum kom enn fremur í ljós að nemendur virtust átta sig betur á pví námi sem fram fór. Detta endurspeglast í orðum nemenda sem sögðu ,áður fór maður bara með verkin heim og henti peim kannski“ og „petta er pægilegra núna, finnst ég hafa gert meira“. Niguidula (2005) komst að pví að markviss skráning ferlis gæti einmitt leitt til pess að nemendur yrðu meðvitaðri um eigið nám. Í öllum premur viðtölunum nefndu nemendur meðal annars að peir gæetu litið til baka og séð alla pá vinnu sem lægi að baki námi peirra í sjónlistum. Einn nemandi tók svo til orða: „I tíunda bekk getur maður horft yfir allt og bara vá“. Hluti nemenda gerði sér pví grein fyrir mikilvægi ferilbókarinnar og sá ávinning af pví að vinna að henni líkt og Abrami og Barrett (2005) sýndu fram á að væri kostur ferilbókagerðar. 


\section{Einstaklingsmiðun}

Eitt markmiða rannsóknarinnar var að komast að pví hvort nýta mætti rafrænar ferilbækur til аð auka einstaklingsmiðun. Nemendur höfðu val um hvernig færslur peir settu í ferilbókina og gátu pví valið að skjalfesta ferlið á fjölbreyttan hátt. Í töflunni hér að neðan má sjá pær tegundir færslna sem nemendur völdu og í hversu mörgum ferilbókum sú tegund var notuð, en heildarfjöldi ferilbóka var 87.

Tafla 1. Tegundir og fjöldi færslna

\begin{tabular}{lc}
\hline Tegund færslna & Fjöldi ferilbóka \\
\hline Ljósmynd af eigin vinnu & 81 \\
Texti & 77 \\
Ljósmynd af neti & 73 \\
Hlekkur (e. link) & 10 \\
Greyptar færslur (e. embedded content) & 7 \\
Stop motion myndskeið & 4 \\
Glærusýning & 3 \\
Hröðunarmyndband ${ }^{2}$ (e. time lapse) & 3 \\
Veggspjald í Pages & 2 \\
PDF & 1 \\
Flash cards & 1 \\
Klippimynd (e. pic collage) & 1 \\
Stafræn teikning & 1 \\
Gif & 1 \\
Hlaðvarp & 1 \\
Myndskeið & 1 \\
Skannaðar kennsluleiðbeiningar & 1 \\
Vlog ${ }^{3}$ (e. video log) & 1 \\
\hline
\end{tabular}

prátt fyrir að nemendum hafi staðið til boða að setja inn færslur í pví sniði sem peir helst kusu völdu flestir nemendur að setja inn texta og myndir, sér í lagi í upphafi. Pað var ekki fyrr en undir lok skólaárs sem nemendur fóru í auknum mæli að setja inn öđruvísi færslur á borð við vlog og hröðunarmyndbönd (e. time lapse), sjá Töflu 1. Рað voru pó ekki nema örfáir nemendur sem nýttu sér pessar leiðir. Hins vegar nefndu 23\% nemenda pað sérstaklega í rafrænni könnun að peir væru ánægðir með að geta valið fjölbreyttar tjáningarleiðir og var pað mikið nefnt sem einn mikilvægasti páttur ferilbókagerðarinnar. Einn nemandi tók svo til orða í rýniviðtali: „Фað er svo pægilegt að hafa petta frelsi." Detta hefði ekki verið hægt nema með peim möguleika að nýta ofurmiðlun (e. hypermedia) en pað er einmitt einn helst kostur rafrænna ferilbóka fremur en hefðbundinna, líkt og Barrett (2011) komst að. 
Með pví að bjóða nemendum upp á að velja pann tjáningarmiðil sem peir kjósa taldi ég mig vera að minnka aðgreiningu nemenda á grundvelli getu peirra í að skila skriflegum verkefnum. Pað er í takt við skóla án aðgreiningar par sem nemendur eru ekki greindir út frá páttum sem peir hafa ekki tök á að breyta. Rafrænar ferilbækur hafa ýmsa möguleika til annars konar tjáningar sem getur pannig stutt við ólíka nemendur eins og Hicks o.fl. (2007) og Niguidula (2005) benda á. Dannig geta nemendur einnig upplifað sig sem sjálfstæða námsmenn í stað vanhæfra einstaklinga en pað er eitt af pví sem Reid (2005) telur að sé mikilvægt í námi nemenda.

Ferilbækurnar staðfestu petta að einhverju leyti en til dæmis valdi einn nemandi að taka upp vlog (e. video $\log$ ) í stað skriflegrar ígrundunar samanber ferilbók nemandans. Hann taldi sig ekki mjög færan í stafsetningu og valdi að ígrunda munnlega í staðinn. Рað samræmist áherslum Norwich (2013) á félagsfræðilega nálgun á sérparfir nemenda sem gerir ráð fyrir pví að aðlaga purfi umhverfi að nemendum en ekki öfugt.

Frelsi til aðlögunar á útliti og uppsetningu var endurtekið stefí rafrænum könnunum, rýnihópum, umræðum og færslum í ferilbókum nemenda en 10\% nemenda tóku pað sérstaklega fram í rafrænni könnun. Nemendur sögðu að peim pætti mikilvægt að geta sett inn efni að eigin vali, myndir, myndskeið, texta og tónlist. Peir vildu frelsi í útliti ferilbókarinnar og var einn nemandi ósáttur við takmörkun á leturgerðum í Padlet, en par er eingöngu boðið upp á fjórar leturgerðir og einn nemandi sagðist vilja „flottari bakgrunn“. Síðan pá hefur Padlet aukið úrval bakgrunnsgerða til muna sem og sett inn möguleikann á að setja inn hvaða mynd sem er. Leturgerðirnar eru pó enn einungis fjórar.

Aukið frelsi krefst hins vegar aukins sjálfstæðis líkt og Niguidula (2005) hefur komist að en rafræna könnunin leiddi í ljós að tveir nemendur hefðu viljað hafa ögn minna frelsi. Sem dæmi sagði annar nemandinn „,mér finnst gott pað að láta segja mér hvað ég á að gera“ og hinn tók í sama streng og sagði „,mér finnst líka að kennarinn megi segja kannski smá til“.

\section{Eignarhald og skuldbinding}

Eignarhald var áberandi páttur í tengslum við ferilbókagerðina. Í rafrænni könnun var frelsi til aðlögunar og stjórn og eignarhald nefnt 26 sinnum sem pættir sem nemendur töldu sig hafa græett á ferilbókagerðinni, sjá Mynd 1. Enn fremur voru rúm $80 \%$ nemenda sem upplifðu að peir ættu hlutdeild í náminu líkt og fram kom í rafrænum könnunum, sjá Mynd 2. Detta kom einnig fram 1 rýniviðtölum en einn nemandi tók svo til orða: „Detta er bara svona minn hlutur.“ Nemendur voru sjálfir ábyrgir fyrir ferilbókinni og höfðu pví tækifæri til virkrar pátttöku í eigin merkingarsköpun líkt og rannsókn Love og Cooper (2004) leiddi í ljós. Einn nemandi sagði „mér finnst svo mikilvægt að fá sjálfstæði og byrja að mynda sjálfstæða hugsun“. Annar nemandi sagðist vilja vita í hvað hann hefði eytt tímanum en með pví að gefa nemendum tækifæri til pess að átta sig á pví námi sem hefur átt sér stað taldi ég hugsanlegt að auka sjálfstraust nemenda sem getur haft bein áhrif á námsárangur líkt og Niguidula (2005) bendir á. 


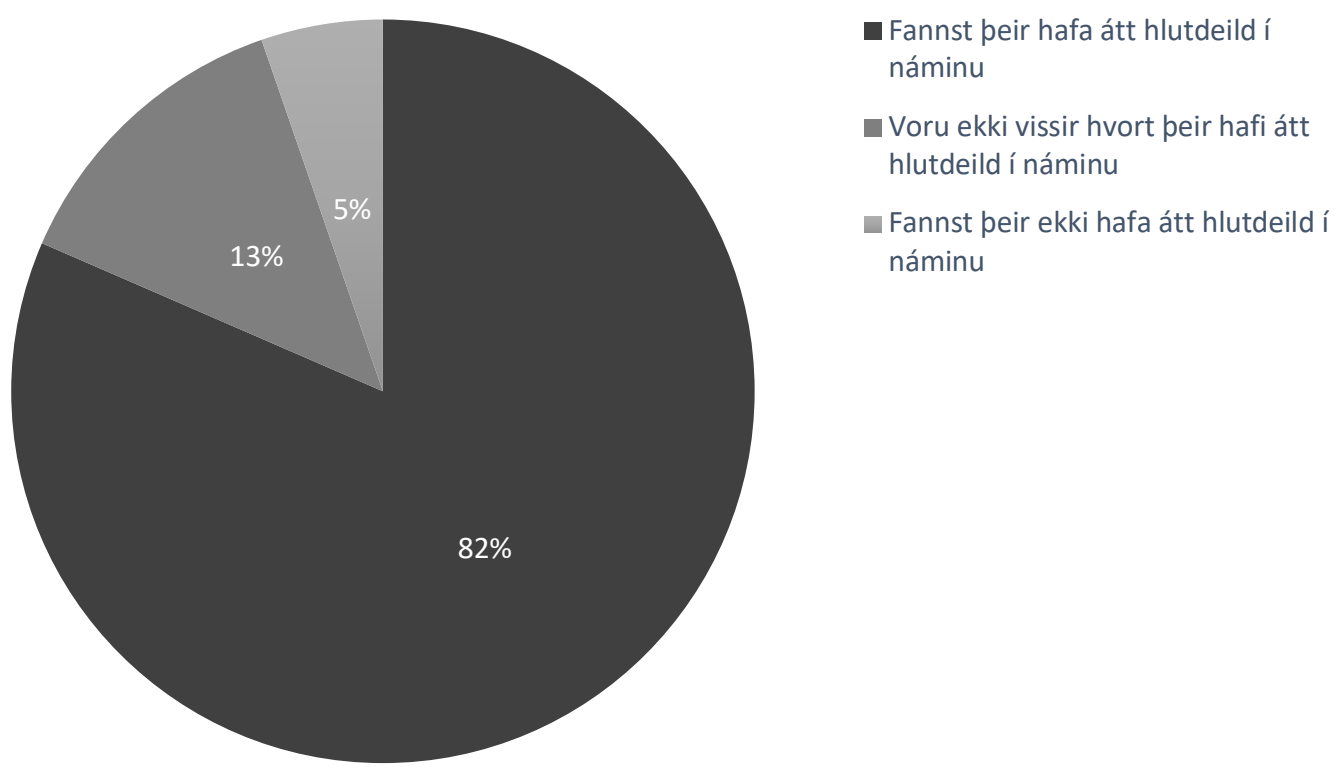

Mynd 2. Álit nemenda á pví hvort peir hefou átt hlutdeild í náminu.

Aðspurðir hvort pað væri mikilvægt að peir hefðu áhrif á ferilbókagerðina, voru eingöngu 4 nemendur af 87 sem ekki töldu pað mikilvægt og var alveg sama eða voru ekki vissir, sjá Mynd 3. Yfir helmingur nemenda nefndi í rafrænni könnun að peim pætti mikilvægt að geta aðlagað ferilbókina og haft áhrif á útlit og uppsetningu. Rýniviðtölin staðfestu petta en í peim öllum nefndu nemendur mikilvægi pess að ferilbókin væri peirra eigin sem endurspeglast í orðunum „ég fæ meiri stjórn, petta er mitt verkefni“ og ,ég vil fá að stjórna sem mestu“. Í gegnum rafræna ferilbókagerð upplifðu nemendur einnig að peir hefðu meiri stjórn á verkefninu. Einn nemandi sagði „parna get ég gert allt sem ég vil“ í rýniviðtali og upplifði að prátt fyrir að ferilbókgerðin væri rammi, pá væri frelsi innan rammans. Pað pýðir hins vegar ekki að verkefnið sé ekki skýrt en einn nemandi tók fram: „Фаð er alltaf verkefni en maður ræður samt svo miklu, pað er svo pægilegt að hafa petta frelsi.“

\section{Finnst pér mikilvægt að fá að hafa áhrif á ferilbókagerðina?}

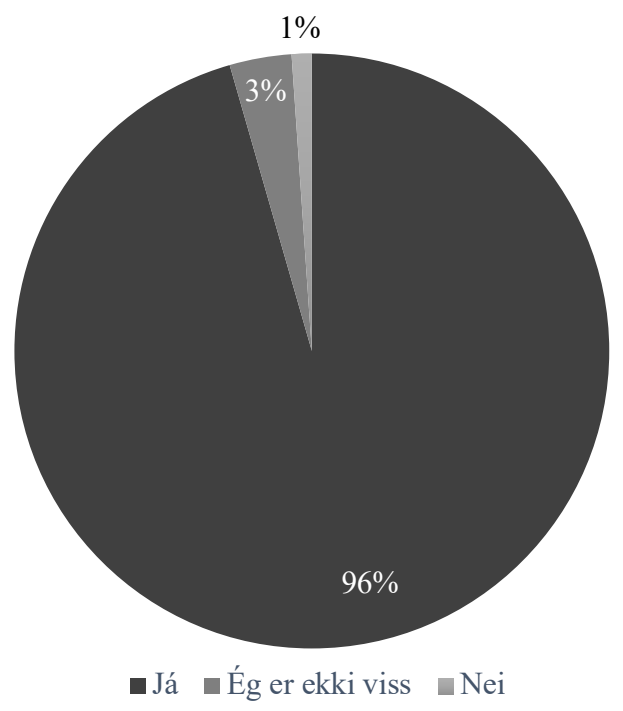

Mynd 3. Skoðun nemenda á pví hvort mikilvægt sé að peir fái að hafa áhrif á ferilbókagerðina, samanber rafræna könnun. 
Hugsanlega getur eignarhald nemenda á ferilbókunum leitt af sér aukna skuldbindingu en í rýniviðtali sagði einn nemandi „mér fannst skemmtilegt að segja frá hlutunum, segja frá hvað gerðist og búa til sögu um pað hvernig petta próaðist hjá mér". Detta samræmist einnig niðurstöðum Love og Cooper (2004) sem segja virka pátttöku í eigin merkingarsköpun mögulega með ferilbókagerð. Pá sagði einn nemandi „,maður getur líka gert heima“ og vísaði par til Padlet-forritsins sem hann notaði heima við til að vinna að ferilbókinni.

\section{Ígrundun}

Nemendur voru langflestir sáttir við að ígrunda við lok hverrar kennslustundar, samanber rannsóknardagbækur. Einn nemandi taldi pað pó tilgangslaust, sá ekki ávinning af pví og tók pað sérstaklega fram í rafrænni könnun. Aðspurðir í rýniviðtali tóku tveir nemendur fram að pað væri of pétt að ígrunda eftir hvern tíma og sagði annar „kannski bara fyrst og síðast“ sem hinn staðfesti með orðunum „pað er of mikið að gera pað í hverjum tíma“. Ferilbækur nemenda reyndust pví vettvangur til ígrundunar eins og fram kemur hjá Hicks o.fl. (2007) og Niguidula (2005) en hugsanlega pótti nemendum hún ópörf við lok hvers tíma.

Undir lok skólaársins höfðu nemendur orð á pví hversu mikilvæg ígrundunin væri. Í rýniviðtölum var mikilvægi pess að geta skrifað texta í ferilbók nefnt af um 14\% nemenda, sjá Mynd 4. Detta kom einnig fram í umræðum, samanber rannsóknardagbækur, og rýniviðtölum. Dar sagði einn nemandi „ef við sleppum ígrunduninni pá vitum við ekki neitt og munum ekki aðferðina“. Dví tengdi hluti nemenda ígrundun við ákveðna skrásetningu og töldu að ígrundun hjálpaði peim að muna aðferðir og tækni sem peir beittu sjaldan og gætu pví rifjað upp síðar meir. Dó tók einn nemandi svo til orða pegar hann var spurður um tilgang ígrundunar: „Við ígrundum til að læra.“ Pað er áhugavert út frá áherslum Ma og Rada (2005) á markvissa ígrundun sem tækifæri til pess að skapa merkingu út frá eigin upplifunum.

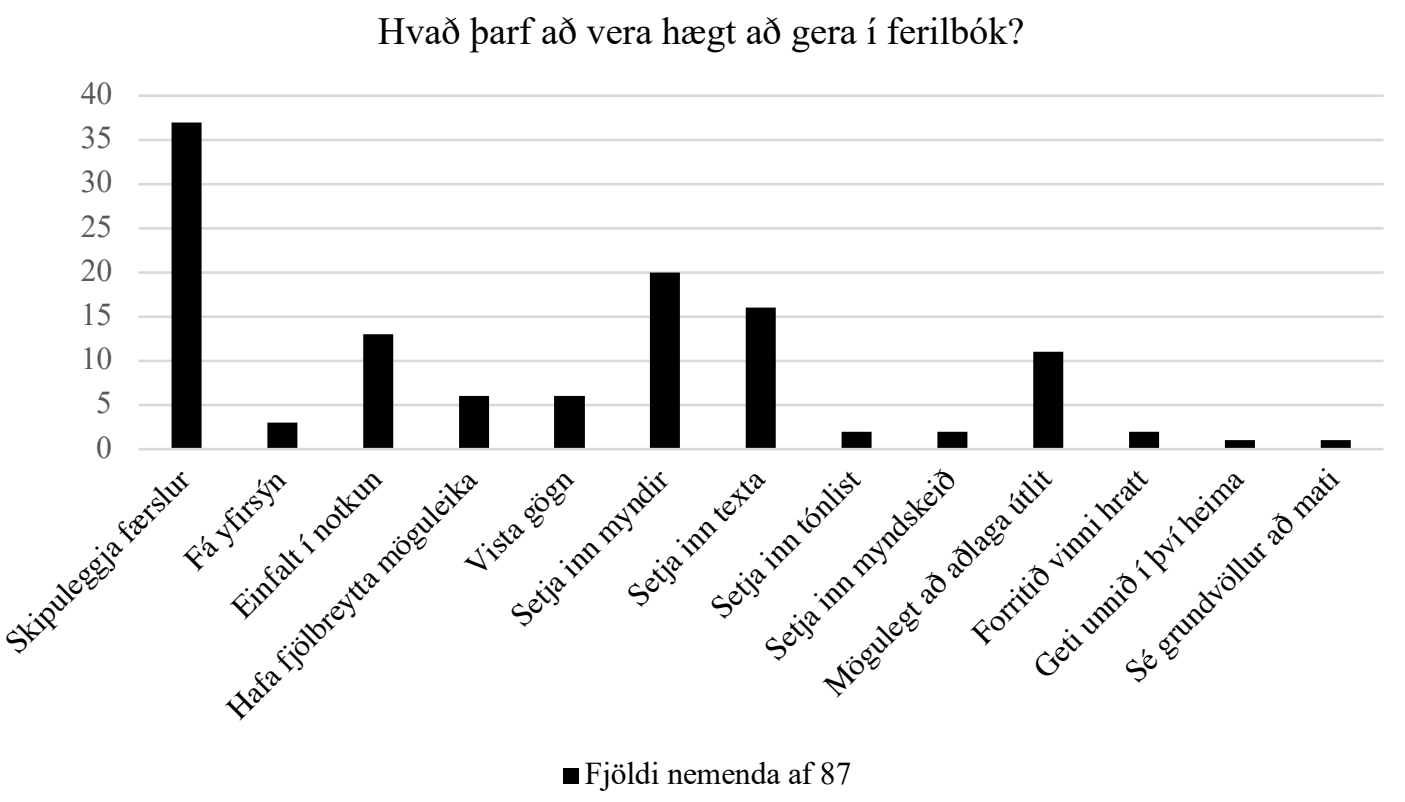

Mynd 4. Pættir sem nemendur töldu mikilvægt að hægt væri að gera í ferilbókaforriti, samanber rafræna könnun.

Í upphafi áttu nemendur oft erfitt með að átta sig á hvað ígrundun fæli í sér, samanber dagbækur. pá voru leiðbeiningar til nemenda munnlegar. Ég útbjó síðan leiðbeiningar sem samanstóðu af spurningum sem nemendur gætu spurt sjálfa sig og velt fyrir sér pví sem peir höfðu gert, hvernig pað hafði tekist, hvort peir myndu breyta einhverju ef peir gerðu pað sama aftur og hvað peir höfðu lært. Greinilegur árangur var af pessum leiðbeiningum par sem ígrundun nemenda lengd- 
ist og dýpkaði samanber orðafjölda í ferilbókum, sjá Mynd 5. Niguidula (2005) hefur skrifað um mikilvægi aðgengilegra leiðbeininga varðandi ígrundunina ef vel á að takast og var sú leið farin á seinni tímabilum. Darling (2001) heldur pví fram að nemendum sé ekki tamt að stunda ígrundun og pað kom bersýnilega í ljós í rannsókninni. Nemendur purftu stöðuga áminningu um eðli og markmið ígrundunar og ég hefði purft að standa betur að peim pætti, en Cleveland (2018) hefur bent á að erfiðlega geti gengið að innleiða ígrundun sem markvissan pátt í námi og kennslu.

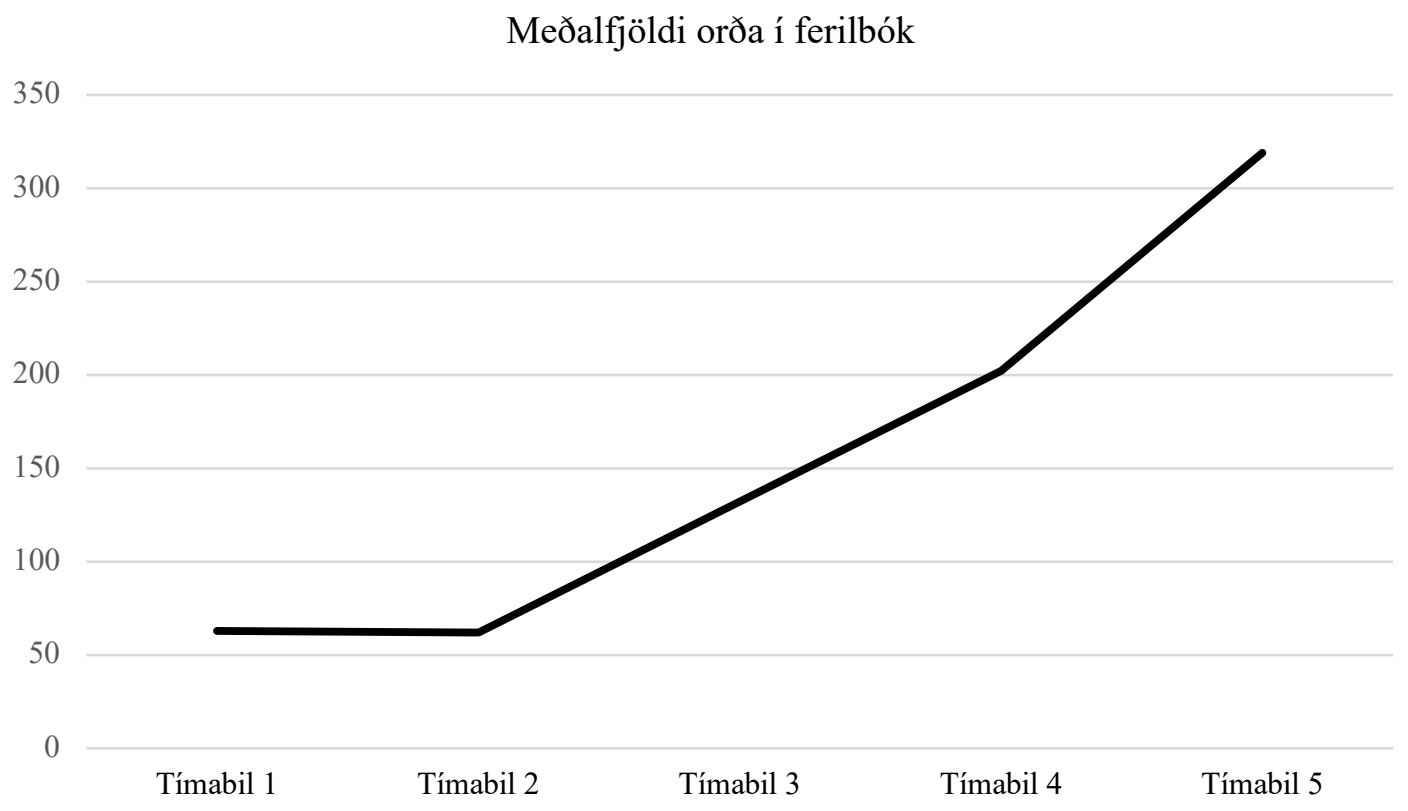

Mynd 5. Meðalfjöldi orða í ferilbókum eftir tímabilum, samanber rafrænar ferilbækur.

\section{Námsstuðningur}

Í gegnum rannsóknarferlið varð mikilvægi námsstuðnings ljóst. Strax á fyrsta tímabili kom í ljós að ef of mörg forrit voru lögð inn í einu, til dæmis ef verkefni kennslustundarinnar krafðist pess að nemendur lærðu á ný forrit, auk ferilbókaforritsins, virtust nemendur missa yfirsýn og töldu ferilbókagerð flókna líkt og fram kom í rafrænni könnun, sjá Mynd 6. Nemendum gekk hins vegar betur pegar peir fengu svigrúm til pess að læra fyrst á ferilbókaforritið áđur en önnur forrit voru kynnt til sögunnar, samanber tímabil 3 til 5. Sýn peirra á ferilbókagerðina var einnig jákvæðari eins og fram kom í rafrænum könnunum en á tímabili 5 var eingöngu einn nemandi af 30 sem var ekki jákvæður gagnvart pví að búa til rafræna ferilbók og sagði „,pað hefði getað gengið betur“. Rýniviðtölin staðfestu pessa upplifun en einn nemandi sagði „,maður var fyrst smá stund að ná að læra hvernig á að logga sig inn, síðan var petta ekkert mál“ á meðan annar tók svo til orða „,petta gekk illa fyrst en síðan betur, fyrst var ég með neikvæðar tilfinningar gagnvart pessu en núna skil ég petta“. 


\section{Prósentuhlutfall nemenda sem taldi ferilbókagerðina flókna}

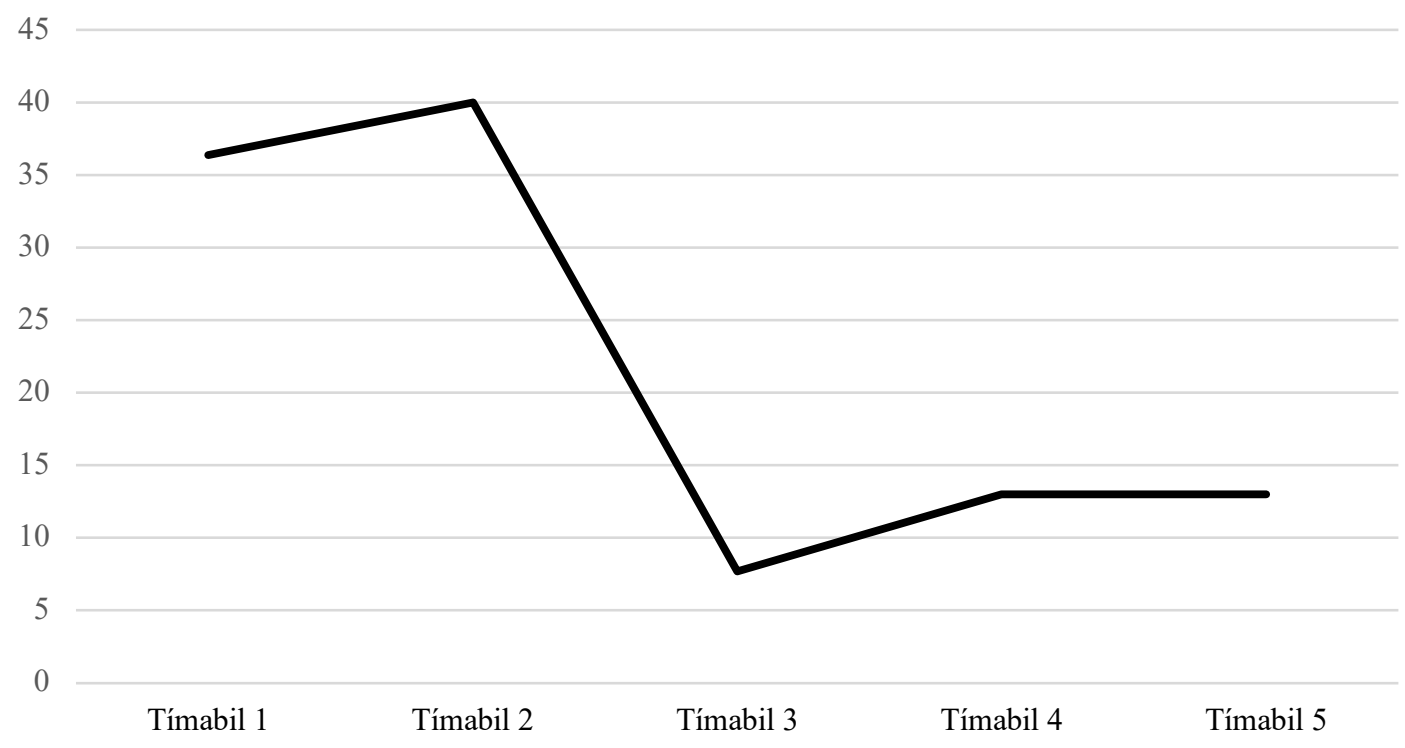

Mynd 6. Prósentuhlutfall nemenda sem taldi ferilbókagerðina flókna, samanber rafræna könnun.

Degar leið á skólaárið gekk betur að auka við færni nemenda og kynna peim smám saman ný forrit og fjölbreyttar leiðir til tjáningar, samanber dagbækurnar sem ég hélt. Í gegnum petta ferli sá ég hvernig má nýta markvissan námsstuðning en Dickson, Chard og Simmons (1993) leggja áherslu á að gæta pess að leiða nemendur skref fyrir skref í gegnum nýjar aðferðir. Að minnsta kosti einum nemanda af 87 pótti leiðbeiningar og aðstoð pó ekki næg og tók svo til orða pegar hann var spurður hvort eitthvað hefði mátt fara betur „kannski sagt leiðbeiningarnar meira pví pað er ekki mikil hjálp“.

Degar leið á skólaárið urðu nemendur heilt yfir sjálfstæðari, samanber dagbækur. Deir voru jafnframt iðnir við að aðstoða hver annan. Detta kom í ljós pegar nýir nemendur komu í sjónlistir. Deir nemendur sem höfðu komið áður kenndu skólasystkinum sínum á ferilbókaforritið og aðstoðuðu pá við fyrstu skrefin. Pegar leið á skólaárið voru nemendur duglegir að benda hver öðrum á ýmsar bjargir sem voru peim aðgengilegar í kennslurými eða rafrænt. Detta bendir til pess að ábyrgð peirra á eigin námi, sem og námi samnemenda sinna, virtist hafa aukist líkt og Wass, Harland og Mercer (2011) telja geta verið áhrif námsstuðnings.

Dað var pó ekki nóg að setja upp hinar ýmsu bjargir heldur purfti ég ítrekað að minna nemendur á leiðbeiningarnar og að nýta sér pær. Parna virtist skipta máli að halda innleiðingu aðferða til streitu og veita nemendum markvissan námsstuðning. Sem dæmi sagði einn nemandi í rýniviðtali: „, Pú varst alltaf að minna okkur á að setja inn, pað var gott.“

Tæknin spilaði ákveðinn pátt par sem miklu skipti að hún virkaði vel. Ef nemendur lentu í vandræðum vegna tæknilegra örðugleika var upplifunin önnur líkt og fram kom í rafrænum könnunum. Einn nemandi tók svo til orða í rafrænni könnun „mér fannst petta pínu flókið, stundum virkaði pað ekki“ á meðan annar sagði „,pað var erfitt að logga sig inn en annars virkaði bað bara vel“. Pá var einn nemandi sem nefndi að honum pæetti Padlet ekki virka eins vel í síma. Á pessu sést hversu mikilvægt er að hafa aðgang að góðum búnaði og nettengingu líkt og Heath (2005) og Pecheone, Pigg, Chung og Souviney (2005) sáu í yfirlitsrannsóknum sínum. 


\section{Námsvitund}

Merki um aukna námsvitund sáust að einhverju leyti undir lok skólaársins pegar nemendur fóru að aðlaga útlit, uppsetningu og færslur ferilbókarinnar. Í fyrstu völdu nemendur að nýta hefðbundnari tjáningarmiðla, p.e. texta og mynd, líkt og ádur hefur komið fram. Nemendur byrjuðu síðan að prófa sig áfram og setja inn annars konar færslur og undir lok tímabils 5 höfðu nemendur valið allt að 18 ólíkar tegundir færslna, sjá Mynd 7 og Töflu 1. Á seinni tímabilum fóru einhverjir nemendur að setja inn fjölbreyttar færslur af sjálfsdáðum á meðan hluti nemenda valdi að setja inn eingöngu eina tegund færslna. Deir nemendur sem komu oftast í sjónlistir fóru að halda sig við sömu tegund af sniðmáti á Padlet og setja bækurnar upp á svipaðan hátt. Peir völdu oft bakgrunn og stíl sem myndaði heildrænt útlit pvert á ferilbækurnar. Dessi atriði benda til pess að nemendur hafi komist skrefinu nær pví að aðlaga námið að eigin námsstíl og efla eigin námsvitund, samanber Reid (2005).

\section{Tegundir færslna eftir tímabilum}

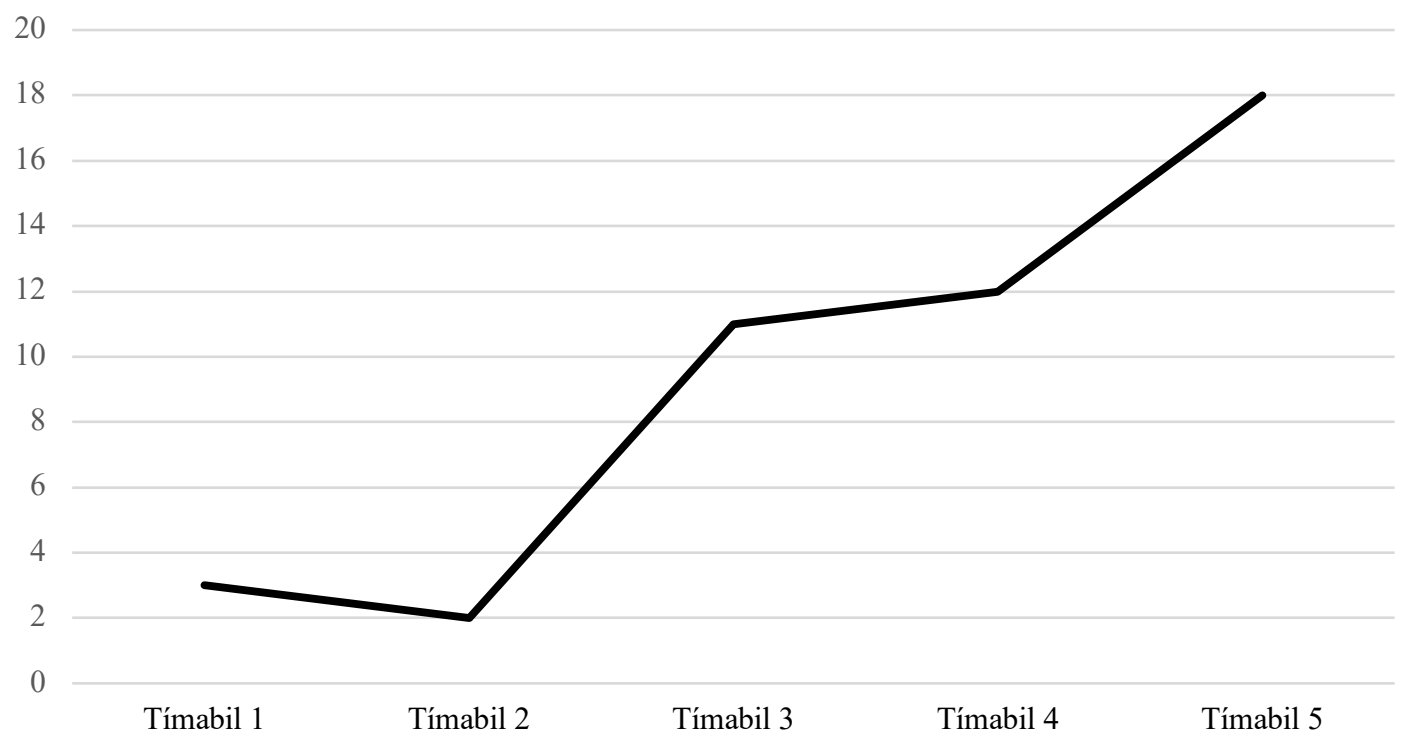

Mynd 7. Fjöldi ólíkra tegunda færslna eftir tímabilum, samanber rafrænu ferilbækurnar.

Í rýniviðtölum kom í ljós að nemendur lærðu af reynslunni og höfðu ferilbækurnar par einhver áhrif. Til dæmis sagði einn nemandi: „Fyrsta myndin mín var fín og auðveld, svona byrjun, síðan var næsta myndin erfiðari og gekk ekki alveg eins vel. En núna erum við ennpá að nota sömu aðferðina og pað gengur miklu betur. Gengur hraðar. Gengur vel. Dað er sniðugt að hafa svona aðferðir. Mér finnst pað pægilegt.“ Detta samræmist sýn Fahey og Cronen (2016) sem telja meginkost ferilbóka vera að gefa nemendum færi á að skapa eigin pekkingu út frá reynslu par sem pekkingin er aukaafurð ferlisins.

Nemendur höfðu betri yfirsýn á námið og stunduðu stöðuga ígrundun samanber ferilbækur nemenda en Reid (2005) hefur greint bæði yfirsýn og ígrundun sem lykilpætti í pví að efla námsvitund nemenda. Eisner (2002) tekur í sama streng og nefnir ígrundun og túlkun sem meginatriði sem stuðli að námsvitund. Hins vegar voru lítil merki um túlkun að finna í ferilbókunum.

\section{Samantekt og ályktanir}

Niðurstaðan er sú að rafrænar ferilbækur höfðu ávinning í för með sér, bæði fyrir nemendur og mig sem kennara. Pær voru ein leið til að auka einstaklingsmiðun í samræmi við hugmyndir um hana 
en pað er pví mín ábyrgð, líkt og annarra kennara, að starfa eftir stefnunni. Ritun og lestur getur verið sumum nemendum fjötur um fót en pegar námið verður rafrænt opnast nýir möguleikar. Ég tel að hluti minna nemenda vilji nýta sér pann kost að taka upp hljódupptöku eða nýta sér raddinnslátt í stað hefðbundinnar ritunar. Dað tel ég skrefí átt að aukinni einstaklingsmiðun. Dví má álykta að rafræn útgáfa af ferilbókum sé um margt hentugri en sú hefðbundna í pessu tilliti par sem hún opnar á möguleikann á fjölbreyttum færslum í gegnum ofurmiðlun (e. hypermedia). Aðbúnaður skipti miklu máli en ég hefði ekki getað farið af stað með pessa innleiðingu ef ekki væri fyrir aðgang að iPad spjaldtölvum. Skólinn á nokkur sett af iPödum sem kennarar geta bókað og nýtti ég mér pann kost til hlítar.

Ferilbækurnar veittu nemendum mínum umgjörð um nám sitt en með aukinni yfirsýn gátu peir séð framfarir sínar og hvernig hæfni peirra hafði aukist um leið og peir tóku ákvarðanir um næstu skref. Petta tel ég að geti nýst nemendum mínum í námi sem og mér sem kennara til pess að fylgjast með framvindu nemenda minna. Nemendur tóku endurtekið fram í rafrænum könnunum að peir töldu að peir hefðu ekki getað sinnt náminu jafn vel ef ekki hefði verið fyrir ferilbókina. Drátt fyrir að peim hefði pótt erfitt að byrja, pá fannst peim fyrirkomulagið mun hjálplegra á pennan hátt miðað við pað sem peir voru vanir. Рað verða pó alltaf einhverjir nemendur sem hvorki sjá tilgang með ferilbókagerðinni né sinna henni að marktæku leyti.

Auk pess að veita nemendum umgjörð um nám sitt, var ferilbókagerðin leið til pess að stuðla að eignarhaldi nemenda minna sem í sumum tilfellum leiddi til aukinnar skuldbindingar og áhuga. Við lok tímabila gátu nemendur litið yfir pað sem peir höfðu gert og áttað sig á að peir höfðu gert meira en peir héldu, sér í lagi pegar lokaafurðin var á einhvern hátt ófullnægjandi að peirra mati. Eldri nemendur gátu sett sig í spor yngri nemenda og ímyndað sér hversu ítarlegar og yfirgripsmiklar ferilbækur peirra yrðu við útskrift par sem peir hefðu unnið markvisst að ferilbókum allt sitt nám í sjónlistum. Dað er að mínu mati mikilvægt að nemendur upplifi ekki að tíma peirra sé illa varið prátt fyrir að peir séu ekki ánægðir með lokaafurðina, sér í lagi ef um er að ræða nemendur sem af einhverjum ástæðum missa úr tíma og ná par af leiðandi ekki að klára.

Í sumum tilfellum voru ferilbækurnar leið til pess að auka sjálfstæði nemenda í námi, sér í lagi ef markvissum námsstuðningi var beitt og er pað eitt af helstu verkefnum mínum sem kennara. Рað getur tekið mikinn tíma að veita nemendum nauðsynlegan stuðning en pegar á líður tel ég pað skila árangri. Ég vonast til pess að með tímanum verði nemendur mínir öruggari og aðlagi ferilbókagerðina enn frekar að eigin námsstíl.

Dá voru ferilbækurnar tilvalinn vettvangur fyrir ígrundun nemenda sem er stór páttur í námi. Dví má álykta að mikilvægt sé að gefa nemendum tækifæri og tíma til pess að sinna pessum pætti. Dað er vissulega tímafrekt og pví parf að gera rád fyrir pessari vinnu í kennsluskipulagi, bæði í upphafi pegar nemendur búa til grunninn að ferilbókinni og í lokin pegar nemendur klára ferilbókina fyrir skil. аð er líka mikilvægt að gefa nemendum tíma í lok hverrar kennslustundar til pess að skrásetja, ígrunda og vinna að ferilbókinni.

Dau atriði sem kynnt hafa verið hér að framan benda öll til pess að notkun ferilbóka geti leitt til öflugri námsvitundar nemenda. Að búa til námsumhverfi og beita kennsluháttum sem gera nemendum kleift að auka námsvitund sína er lykilatriði í kennslu en eitt peirra verkefna sem kennarar standa frammi fyrir er að veita nemendum námstækifæri sem nýtast peim í áframhaldandi námi. Ólíklegt er að stór hluti nemenda muni starfa við listsköpun og pví mikilvægt að leggja áherslu á merkingarbært nám og yfirfærslu pekkingar. Rannsóknin sneri að notkun ferilbóka í sjónlistum en ég tel að pær gætu nýst með sambærilegum hætti í öðrum list- eða verkgreinum og jafnvel í öðrum fögum. 


\section{Digital portfolios to enhance metacognition. Action research in visual arts}

Modern teaching is influenced by the ideas of inclusive schools where all students are provided with a quality education, regardless of their needs (Menntavísindastofnun Háskóla Íslands [University of Iceland Educational Research Institute], n.d.). This is the task teachers face daily. To do so they need to use a variety of teaching strategies that suit each student's individual needs which can be a daunting task. Being able to use methods that each student can adjust to own abilities and provide multiple ways of expression and communication, can be an advantage. Teaching visual arts, $\mathrm{I}^{4}$ needed to find a way to let my students record their creative process as well as their learning, all the while using inclusive methods. It was my hope that creating digital portfolios would be a way to meet this goal.

This paper reports findings from action research where I implemented the use of digital portfolios in my own visual arts teaching among thirteen to fifteen-year-old students. The aim was to integrate inclusive teaching methods as a way to enhance metacognition. The study was an action research project conducted during the school year of 2017- 2018 where I focused on developing my own teaching methods and supporting professional enhancement with continuous reflection on the intervention at hand. The school year was divided into five periods which coincided with the five phases of the action research. In total, 87 students participated, 50 girls and 37 boys. 33 students joined more than one phase, some participated in up to three phases.

The research question was as follows: how can digital portfolios support inclusion in visual art teaching? Data was collected in five different ways, (1) discussion groups between the researcher and the students at the beginning of each of the five phases, (2) my researcher journals, written up during all five phases, (3) an anonymous online survey that the students answered at the end of each phase, (4) evaluation of the students' digital portfolios and (5) focus groups among a sample of students from each year, consisting of four students each; three focus groups in total. The data was processed continuously through the five phases and the intervention revised on a regular basis.

To create the portfolios, students used the Padlet app. Padlet is a website (padlet. com) and an app, formerly known as Wallwisher whose primary purpose is to create so called walls that provide a visual overview. Users can post multimedia posts, including, but not limited to, photos, texts, videos, voice recordings and links. It also enables you to embed web content unto the wall. Its primary benefit for teachers and students is that it provides a subscription for schools which lets teachers manage the students' accounts. Padlet also runs on iOS and Android operating systems.

The results indicate that digital portfolios can have multiple benefits, both for students and teachers. They were a way to enhance inclusion and independence in my students' learning. They can give students added ownership of their own work which, in turn, can lead to increased commitment. Digital portfolios can be a way to manage learning and encourage reflection if systematic scaffolding is provided, which can lead to increased metacognition. These results indicate that digital portfolios may lead to enhanced metacognition, a fundamental part of learning. To create a learning environment and use teaching methods that enable students to enhance their metacognition is one of the tasks I face as a teacher. I believe digital portfolios can be a way towards that goal. This research focused on the usage of digital portfolios in the teaching and learning of visual arts; however, the method might benefit teachers and students of other subjects.

Key words: Digital portfolios, visual arts, differentiated learning, reflection, metacognition 


\section{Um höfunda}

Sandra Rebekka Önnudóttir Arnarsdóttir (sandra.arnarsdottir@unak.is) er sjónlistakennari við Giljaskóla á Akureyri. Hún brautskráđist frá Háskóla Íslands árið 2011 með B.Ed.-gráðu í kennslu með áherslu á myndlist. Síðar lauk hún priggja ára diplómunámi frá Myndlistaskólanum á Akureyri. Sandra Rebekka lauk M.A.-gráđu árið 2014 með áherslu á sérkennslufræði. Hún hefur starfað sem sjónlistakennari síðan árið 2015 og sem stundakennari við Háskólann á Akureyri frá árinu 2017. Sandra Rebekka hefur einnig sinnt kennslu við Myndlistaskólann á Akureyri frá árinu 2016 sem og sinnt annarri kennslu. Einnig hefur hún tekið pátt í fjölda listsýninga sem og haldið sínar eigin. Hennar helstu áherslur í starfi eru listkennsla, notkun skapandi aðferða og tækni í kennslu, réttur nemenda til lýðræðislegar pátttöku í eigin námi og réttur barna til náms.

Hermína Gunnpórsdóttir (hermina@unak.is) er prófessor við Háskólann á Akureyri. Hún hefur B.A.-próf í íslensku og uppeldis- og kennslufræði frá Háskóla Íslands, meistarapróf frá Kennaraháskóla Íslands (2003) og doktorspróf frá Háskóla Íslands (2014). Hún hefur starfað við leik-, grunn- og framhaldsskóla. Helstu viðfangsefni hennar í kennslu og rannsóknum eru skóli og nám án aðgreiningar, fjölmenning og nám, félagslegt réttlæti í menntun, fötlunarfræði, menntastefna og framkvæmd hennar.

Jórunn Elídóttir (je@unak.is) er dósent við kennaradeild hug- og félagsvísindasviðs Háskólans á Akureyri. Hún er leikskólakennari, lærði sérkennslufræði í Noregi (19831988) og lauk doktorsprófi í sérkennslufræðum frá Worcester University 2002. Hún var á árum áđur leikskólasérkennari, sérkennari og sérkennsluráđgjafi í grunnskólum. Kennslu- og rannsóknarsvið hennar eru skóli án aðgreiningar, sérkennslufræði, leikskólafræði og málefni er varða ættleidd börn.

\section{About the authors}

Sandra Rebekka Önnudóttir Arnarsdóttir (sandra.arnarsdottir@unak.is) is a visual arts teacher at Giljaskóli in Akureyri. She holds a B.Ed. in teaching with emphasis on visual arts. She later completed a three year course in Fine Arts from the Akureyri School of Visual Arts. Sandra Rebekka completed an M.A degree in the Education of SEN students in 2014. She has held the position of a visual arts teacher since 2015 and taught occasionally at the University of Akureyri since 2017. Sandra Rebekka has also taught at the Akureyri School of Visual Arts since 2016 as well as at other places. She has participated in a number of art shows, as well as organising her own shows. She emphasises teaching art and the usage of creative teaching methods as well as the role of technology in teaching. Her focus is also on students' right to democratic participation in their own learning and children's right to education.

Hermína Gunnpórsdóttir (hermina@unak.is) is a Professor at the University of Akureyri. She holds a B.A. degree in Icelandic and a teaching certification from the University of Iceland, a master's degree from the Iceland University of Education (2003) and a PhD from the University of Iceland (2014). She has worked at kindergarten, primary and secondary schools. Her teaching and research interest relates to the inclusive school and education, multiculturalism and education, social justice in education, disability studies, educational policy and practice.

Jórunn Elídóttir (je@unak.is) is a senior lecturer at the Faculty of Education, School of Humanities and Social Sciences, University of Akureyri. She is an early childhood teacher, studied special education in Norway (1983-1988) and completed a PhD in special education from Worcester University in 2002. She has been a special preschool 
teacher as well as a specialist teacher and counsellor in special education at compulsory school level. Her research interests concern special education, inclusive education, early childhood education and adopted children.

\section{Heimildir}

Abrami, C. P. og Barrett, H. (2005). Directions for research and development on electronic portfolios. Canadian Journal of Learning and Technology, 31(3). doi:10.21432/T2RK5K

Anna Kristín Sigurðardóttir. (2013). Skóli sem lærdómssamfélag. Í Rúnar Sigpórsson, Rósa Eggertsdóttir og Guðmundur Heiðar Frímannsson (ritstjórar), Fagmennska i skólastarfi: Skrifað til heiðurs Trausta Dorsteinssyni (bls. 35-51). Reykjavík: Háskólinn á Akureyri og Háskólaútgáfan.

Ástríður Stefánsdóttir. (2013). Eigindlegar rannsóknir og siðferðileg álitamál. Sérrit Netlu 2013 - Rannsóknir og skólastarf. Sótt af http://netla.hi.is/serrit/2013/rannsoknir_og_skolastarf/002.pdf

Barrett, H. (2011). Researching electronic portfolios and learner engagement: The reflect initiative. Journal of Adolescent and Adult Literacy, 50(6), 436-449. doi: 10.1598/JAAL.50.6.2

Canada, M. (2002). Assessing e-folios in the online class. New Directions for Teaching and Learning, 91, 69-75.

Chi-Cheng, C. og Bing-Hong, W. (2012). Is teacher assessment reliable or valid for high school students under a web-based portfolio environment? Educational Technology E Society, 15(4), 265-278.

Cleveland, R. E. (2018). Using digital portfolios: Reflection, assessment and employment. Teach Trends, 62(3), $276-285$.

Darling, L. F. (2001). Portfolio as practice:The narratives of emerging teachers. Teaching and Teacher Education, 17(1), 107-121.

Dickson, S.V., Chard, D. J. og Simmons, D. C. (1993). An integrated reading/writing curriculum: A focus on scaffolding. LD Forum, 18(4), 12-16.

Eisner, E. (2002). The arts and the creation of mind. New Haven, CT:Yale University Press.

Ensk-íslensk orðabók með alfræðilegu ívafi. (e.d.). Sótt af https://snara.is/

Fahey, P. og Cronen, L. (2016). Digital portfolios in action: Acknowledging students' voice and metacognitive understanding in art. The Clearing House: A Journal of Educational Strategies, Issues and Ideas, 89(4-5), 135-143. doi:10.1080/14759390600923535

Fræðslumiðstöð Reykjavíkur. (1998). Starfsáctlun Fræðslumiðstöðvar Reykjavíkur 1999. Reykjavík: Höfundur.

Fræðslumiðstöð Reykjavíkur. (1999). Starfsáatlun Fræðslumiðstöðvar Reykjavíkur 2000. Reykjavík: Höfundur.

Hafpór Guðjónsson. (2011). Kennarinn sem rannsakandi. Rádstefnurit Netlu - Menntakvika 2011. Sótt af http://netla.hi.is/menntakvika2011/011.pdf

Hauge, T. E. (2006). Portfolios and ICT as means of professional learning in teacher education. Studies in Educational Evaluation, 32(1), 23-36. Sótt af https://www.sciencedirect.com/science/article/pii/ S0191491X06000034

Heath, M. (2005). Are you ready to go digital? The pros and cons of electronic portfolio development. Library Media Connection, 23(7), 66-70.

Heide, S., Karlin, M., Miles, S. og Ozogul, G. (2016). The practical application of e-portfolios in k-12 classrooms: An exploration of three web 2.0 tools by three teachers. Techtrends: Linking Research \& Practice to Improve Learning, 60(4), 374-380. doi: 10.1007/s11528-016-0071-2

Hicks, T., Russo, A., Autrey, T., Gardner, R., Kabodian, A. og Edington, C. (2007). Rethinking the purposes and processes for designing digital portfolios. International Reading Association, 59(6), 450-458. doi:10.1598/ JAAL.50.6.3

Ingvar Sigurgeirsson. (2005). Um einstaklingsmiðað nám, opinn skóla og enn fleiri hugtök ... . Uppeldi og menntun, 14(2), 9-31. Sótt af https://notendur.hi.is/ingvars/Greinar/GreinIS.pdf 
Jóhanna Einarsdóttir. (2009). Starfendarannsóknir. Sótt af http://menntavisindastofnun.hi.is/sites/menntavisindastofnun.hi.is/files/rannung/umstarfendarannsoknir.pdf

Kristín Pórarinsdóttir og Rúnar Sigpórsson. (2013). Starfenda- og pátttökurannsóknir. Í Sigríður Halldórsdóttir (ritstjóri), Handbók i aðferðafreeði rannsókna (bls. 347-359). Akureyri: Háskólinn á Akureyri.

Love, T. og Cooper, T. (2004). Designing online information systems for portfolio-based assessment: Design criteria and heuristics. Journal of Information Technology Education, 3, 65-81.

Ma, X. og Rada, R. (2005). Building a web-based accountability system in a teacher education program. Interactive Learning Environments, 12(1-2), 93-119.

Mauthner, M. (1997). Methodological aspects of collecting data from children: Lessons from research projects. Children E Society, 11, 16-28. Sótt af https://onlinelibrary.wiley.com/doi/epdf/10.1111/j.1099-0860.1997. tb00003.x

McNiff, J. (2013). Action research: Principles and practice. London: Routledge.

McNiff, J. og Whitehead, J. (2010). You and your action research project (3. útgáfa). London: Routledge.

Mennta- og menningarmálaráđuneyti. (2013). Aðalnámskrá grunnskóla: Almennur hluti 2011: Greinasvið 2013. Reykjavík: Höfundur.

Menntavísindastofnun Háskóla Íslands. (e.d.). Skóli án ađgreiningar. Sótt af http://menntavisindastofnun.hi.is/ skoli_an_adgreiningar

Mills, G. E. (2007). Action research: A guide for the teacher researcher. London: Pearson.

Mukherji, P. og Albon, D. (2010). Research methods in early childhood: An introductory guide. London: Sage.

Niguidula, D. (2005). Documenting learning with digital portfolios. Educational Leadership, 63(3), 44-47. Sótt af http://eric.ed.gov/?id=EJ745456

Norwich, B. (2013). Addressing tensions and dilemmas in inclusive education. London: Routledge.

Nutbrown, C. (2010). Naked by the pool? Blurring the image? Ethical issues in the portrayal of young children in arts-based educational research. Qualitative Inquiry, 17(1), 3-15. doi:10.1177/1077800410389437

Orðabók Aldamóta. (e.d.). Sótt af https://snara.is/

Pecheone, R. L., Pigg, M. J., Chung, R. R. og Souviney, R. J. (2005). Performance assessment and electronic portfolios: Their effect on teacher learning and education. The Clearing House, 78(4), 164-176.

Reid, G. (2005). Learning styles and inclusion. London: Paul Chapman Publishing.

Rosenshine, B. og Meister, C. (1992). The use of scaffolds for teaching higher-level cognitive strategies. Educational Leadership, 49(7), 26-33.

Shernoff, D. J., Csikszentmihalyi, M., Schneider, B. og Shernoff, E. S. (2014). Student engagement in high school classrooms from the perspective of flow theory. Applications of flow in human development and education, 475-494. Sótt af https://link.springer.com/chapter/10.1007/978-94-017-9094-9_24

Sigurður Kristinsson. (2003). Siðfræði rannsókna og siðanefndir. Í Sigríður Halldórsdóttir og Kristján Kristjánsson (ritstjórar), Handbók í aðferðafreðði og rannsóknum í heilbrigðisvísindum (bls. 161-179). Akureyri: Háskólinn á Akureyri.

Smith, K. og Tillema, H. (2003). Clarifying different types of portfolio use. Assessment and Evaluation in Higher Education, 28(6), 625-648.

Stjórnarráð Íslands. (e.d.). Menntun fyrir alla. Sótt af https://www.stjornarradid.is/verkefni/menntamal/menntun-fyrir-alla/

Thomas, G. (2013). A review of thinking and research about inclusive education policy, with suggestions for a new kind of inclusive thinking. British Educational Research Journal, 29(3), 473-490. doi: 10.1080/01411926.2011.652070

Tosh, D., Light, T. P., Fleming, K. og Haywood, J. (2005). Engagement with electronic portfolios: Challenges from the student perspective. Canadian Journal of Learning and Technology, 31(3). doi: 10.21432/T23W31

Wang, M. R. og Holcombe, R. (2010). Adolescents' perceptions of school environment, engagement, and academic achievement in middle school. American Educational Research Journal, 47(3), 633-662. doi:10.3102/0002831209361209 
Wass, R., Harland,T. og Mercer, A. (2011). Scaffolding critical thinking in the zone of proximal development. Higher Education Research and Development, 30, 317-328. doi:10.1080/07294360.2010.489237

Zeichner, K. og Wray, S. (2001). The teaching portfolio in US teacher education programs: What we know and what we need to know. Teaching and Teacher Education, 17(5), 613-621.

Sandra Rebekka Önnudóttir Arnarsdóttir, Hermína Gunnbórsdóttir og Jórunn Elídóttir. (2020).

Rafrænar ferilbækur sem leið að aukinni námsvitund. Starfendarannsókn í sjónlistum.

Netla - Veftímarit um uppeldi og menntun. Menntavísindasvið Háskóla Íslands.

Sótt af http://netla.hi.is/greinar/2020/ryn/07

DOI: https://doi.org/10.24270/netla.2020.7

Endnotes

1 Ég vísar til Söndru Rebekku Önnudóttur Arnarsdóttur sem var sá rannsakandi sem safnađi gögnum á vettvangi.

2 Hröðunarmyndband (e. time-lapse) er myndband par sem hæg atburðarás er kvikmynduð og spiluð mun hraðar (Ensk-íslensk orðabók með alfræðilegu ívafi, e.d.).

3 Vlog (e. video log) er pegar færsla er í myndbandsformi, p.e. viðkomandi talar og fjallar um eitthvað í myndbandsupptöku (Orðabók aldamóta, e.d.).

4 I refers to Sandra Rebekka Önnudóttir Arnarsdóttir, who collected the data.

5 Ég vísar til Söndru Rebekku Önnudóttur Arnarsdóttur sem var sá rannsakandi sem safnaði gögnum á vettvangi

6 Hröðunarmyndband (e. time-lapse) er myndband par sem hæg atburðarás er kvikmynduð og spiluð mun hraðar (Ensk-íslensk orðabók með alfræðilegu ívafi, e.d.).

7 Vlog (e. video log) er pegar færsla er í myndbandsformi, p.e. viðkomandi talar og fjallar um eitthvað í myndbandsupptöku (Orðabók aldamóta, e.d.)

8 I refers to Sandra Rebekka Önnudóttir Arnarsdóttir, who collected the data. 